\title{
THE SUPREME COURT AND THE POLITICAL BRANCHES: DEMOCRATIC THEORY AND PRACTICE*
}

\author{
JESSE H. CHOPER $\dagger$
}

\section{The Conflict Between Majoritarian Democracy and Judicial Review}

The reconciliation of judicial review with American representative democracy has been the subject of powerful debate since the early days of the Republic. Much of the controversy has been due to the large number of varied and often vague theories of "democracy" and to the absence of any clear consensus on its definition and that of other such highly abstract concepts as a "democratic society" and a "democratic political system." But certain critical elements are beyond reasonable dispute. Whether one looks to such classical theorists as Aristotle, Locke and Rousseau, or to such mainstays of American political thinking as Madison, Jefferson and Lincoln, majority rule has been considered the keystone of a democratic political system in both theory and practice. ${ }^{1}$ Effective majoritarianism in turn depends on the preservation of two fundamental rights of the individual, the right to vote and the right freely to express and exchange ideas. Although the nature of operating government permits neither right to be absolute and although complex questions exist as to their precise scope-such as the particular qualifications of those to whom the franchise is to be granted and the permissible restrictions on the freedoms of speech, press and association-the right of persons generally to vote rests at the heart of popular democracy and the intelligent exercise of the ballot demands robust free expression. In theory, the ma-

* Copyright 1974 by Jesse $H$. Choper. This article is an adaptation of a chapter of a book in progress on the proper function of judicial review in respect to different categories of constitutional questions. I wish to express appreciation to Professors Sanford H. Kadish, Paul J. Mishkin, Nelson W. Polsby and Michael E. Smith for their valuable comments.

$\dagger$ Professor of Law, University of California, Berkeley. B.S. 1957, D.H.L. 1967, Wilkes College; LL.B. 1960, University of Pennsylvania. Member, District of Columbia Bar.

${ }^{1}$ See the recitation of these views in R. Dahl, A Preface to Democratic Theory 34-35 (1956) [hereinafter cited as Preface to Democracy]. 
joritarian ideal would be most faithfully fulfilled by having all governmental regulations enacted by plebiscite or, better yet, at national "town meetings" where all electors could participate by framing the issues as well as by casting their ballots. But, because of the cumbersome and impractical quality of these devices, they have been largely rejected in favor of lawmaking by representative assemblies. Thus, although the history of modern democratic theory and the development of American democratic government may call for some amplifications and qualifications, a "democratic political system" may basically be defined as one in which "public policies are made, on a majority basis, by representatives subject to effective popular control at periodic elections which are conducted on the principle of political equality and under [general] conditions of political freedom." 2

If it is not simply antidemocratic when measured by this standard, the federal judiciary, presided over by the United States Supreme Court, is the least democratic of the three branches of American national government. Its membership is appointed rather than elected, removable only by an exceedingly intricate and extra-majoritarian process of impeachment, and protected absolutely against any diminution of compensation. Although such an institution may fit within the broad boundaries of a democratic government, ${ }^{3}$ the lower federal judges and Supreme Court Justices appear to be wholly without political responsibility. This seeming conflict with the principle of majority rule is tempered by the fact that when the federal courts engage in nonconstitutional adjudication their rulings are subject to change by the political branches. But when they exercise the power to declare unconstitutional legislative, executive or administrative action, they reject the product of the popular will by denying policies formulated by the majority's elected representatives or their appointees. Apart from the rarely used and difficult political recourse of constitutional amendment, which

2 H. Mayo, An Introduction to Democratic Theory 70 (1960); see also A. Ranney \& W. Kendall, Democracy and the American Party System 54-55 (1956); McCleskey, Judicial Review in a Democracy: $A$ Dissenting Opinion, 3 Houston L. Rev. 354 (1966).

3 In his "Definition of a Republic," Madison made clear that

it is sufficient for such a government that the persons administering it be appointed, either directly or indirectly, by the people; and that they hold their appointments ... either [for a limited period, or during good behavior] . . . ; otherwise every government in the United States, as well as every other popular government that has been or can be well organized or well executed, would be degraded from the republican character. ... [A]ccording to the most respectable and received opinions on the subject, the members of the judiciary department are to retain their offices by the firm tenure of good behavior.

The Federalist No. 39, at 281 (B. Wright ed. 1961) (J. Madison). 
itself requires substantially more than a simple majority, the Supreme Court's constitutional pronouncements are held to be final-the law of the land. Not merely nonmajoritarian, judicial review appears to cut directly. against the grain of traditional democratic philosophy.

The conclusion that judicial review is antithetical to democracy is by no means an inescapable one, however. The general definition of a "democratic political system" used above to evaluate the judicial branch and the institution of judicial review may legitimately be found incomplete-inadequate, even though not inaccurate. Despite the tendency of many classical and modern democratic political theorists to equate democracy with pure majoritarianism," "the attempt to identify democracy with the unlimited power of majorities has usually gone hand in hand with an attempt to include in the definition some concept of restraints on majorities." Madison, in particular, "wished to erect a political system that would guarantee the liberties of certain minorities whose advantages of status, power, and wealth would, he thought, probably not be tolerated indefinitely by a constitutionally untrammeled majority."5 Furthermore, most contemporary defenders of judicial review explicitly reject the notion that democracy is synonymous with pure majoritarianism. They persuasively contend that the essential values of a democratic society, of a libertarian democracy, assume the existence of certain inalienable minimums of personal freedom, beyond the political rights of the ballot and free expression, that guard the dignity and integrity of the individual. They argue that " $[\mathrm{r}] \mathrm{a}-$ tional limitation on power is . . not a contradiction to democracy, but is of the very essence of democracy as such;"6 that "the object of the men who established the American Constitution, like the object of democratic theorists in all countries, and at all times, was not omnicompetent popular government, but the freedom of man as an individual being within a free society whose policies are based ultimately upon his consenting will."7

The postulate that a truly democratic society stops short of entrusting popular government with unlimited power over all

+ See, e.g., Mace, The Antidemocratic Character of Judicial Review, 60 CAL. L. REv. 1140 , 1145 (1972) (quoting 10 The WrITINGS OF ThOMAS JEFFERSON 89 (P. Ford ed. 1892-99) \& 7 The WRITINGS OF ThOMAS JefFerson 75 (H. Washington ed. 1861)).

5 PREFACE to Democracy, supra note 1 , at 31,35 .

6 C. Black, The Occastons of Justice 75 (1963). (1958).

7 Rostow, The Supreme Court and the People's Will, 33 Notre Dame Law. 573, 577 
individual action is appealing both philosophically and pragmatically. But a critical question remains unanswered: who designates the specific personal liberties that transcend the authority of the state, and who determines when they have been abridged?

Three alternatives come quickly to mind. The first-one which may readily be found unacceptable-is that the individual himself prescribes his inalienable rights. But if "[l]iberty is the right to defy the majority," 8 and if, in a democracy, each person has the unqualified right to define liberty for himself, we have entered a quagmire that rapidly swallows democracy's central feature of majority rule. Indeed, it seemingly conflicts with all governmental rule as that term is ordinarily understood.

A second possible source for designating the appropriate restraints on majoritarianism-the one most compatible with orthodox democratic precepts and implicit in the views of classical democratic theorists ${ }^{9}-$ is the legislative process itself. The sacrosanct liberties of the individual may either be enumerated in some constitutional document or perceived by the people's elected representatives in the course of the operation of the legislative process. Under this view, the assumption (and hope) is that the decisions of the representative bodies will be rational and just and that the social conscience of the majority of the populace-as molded and articulated by its leaders-will prevent invasion of the rights of the minority. In general, this is the scheme in England and in other western democracies with written constitutions. Early confidence for this assumption in American society is found in the fact that the Constitution and the Bill of Rights-containing definite and substantial limitations on both the national and state governments, many in favor of minorities-were promulgated by majorities through the political process. Furthermore, without denying that some serious abridgements of important personal liberties have periodically occurred, American history has shown, certainly at the national level and generally at the state and local levels as well, that with relatively few exceptions-usually regarding peculiarly identifiable, despised and defenseless groups-the political process has not tyrannized minorities. Whether this experience may in part be attributed to the fact that the ever present threat of judicial review has deterred additional political excesses is un-

\footnotetext{
${ }^{8}$ Reich, The New Property, 73 Yale L.J. 733, 774 (1964).

${ }^{9}$ See, e.g., W. Kendall, John Locke and the Doctrine of Majority Rule 134
} (1959). 
known and probably unknowable. But it may be effectively explained by the analysis suggested by Carl Auerbach in describing national politics:

The multiplicity and variety of interest groups in the United States, and the countervailing power they possess, keep any one interest, or combination of interests, from dominating our society. Furthermore, the power of pressure groups, the "mobilizers of minorities," is curbed by the exercise of political power which, in turn, is diffused by our political parties, the "mobilizers of majorities"... And the power of the parties is further checked by that of the pressure groups.

To mobilize a majority of the votes in an election, each political party must appeal to a variety of "interests" and a wide spectrum of opinion. As a consequence of their catholicity, the major parties are unthinkable as instruments of tyranny because "it is impossible for the party in power to oppress any element of the opposition party without oppressing a corresponding element within its own ranks." In addition, the party in power knows that any effort to "tyrannize" a particular minority may also antagonize other groups in the majority coalition, as well as the "independents" pursued by both major parties, and, therefore, may cost it the next election.

In short, the "monolithic" majority . . . does not exist; the majority is but a coalition of minorities which must act in a moderate, broadly representative fashion to -preserve itself. Political conciliation and accommodation characterize the legislative and administrative processes, as well as the competition for votes. This aspect of our political system is accentuated because we do not have disciplined, programmatic political parties and the individual legislative representative is left with a great deal of discretion. ${ }^{10}$

A third method for defining and securing personal freedoms against the popular will-the one favored by champions of judicial review-is to assign this task to some government institution that functions at least somewhat outside the mainstream of the political process. Although a number of possible candidates may be suggested, in the United States the mantle has fallen to the Supreme Court. The theory advanced is that the Supreme

${ }^{10}$ Auerbach, The Reapportionment Cases: One Person, One Vote-One Vote, One Value, 1964 Sup. CT. Rev. 1, 52 (footnotes omitted). 
Court constitutes "a working part of the democratic political life of the nation"11 because the power of judicial review has been historically exercised to restrain the majority from impinging on the constitutionally designated liberties of the individual, thus to assure those ultimate values that are integral to a democracy.

The difficulty with this position is that it commingles substance with procedure. The Supreme Court does advance democratic values by rejecting political action that threatens individual liberty. Its rulings requiring popular policies to adhere to constitutional precepts do enhance the democratic nature of our society. But irrespective of the content of its decisions, the process of judicial review is not democratic because the Court is not a politically responsible institution. ${ }^{12}$ "The Court is not saved from being oligarchic because it professes to act in the service of humane ends." ${ }^{13}$ Although the Supreme Court may play a vital role in the preservation of the American democratic system, the procedure of judicial review is in conflct with the fundamental principle of democracy-majority rule under conditions of political freedom.

Heroic efforts have been made to demonstrate that judicial review is compatible with democratic theory, that in exercising this power the Supreme Court is neither a "bevy of Platonic guardians"14 nor an "aristocracy of the robe"15 nor an "autocratic member of a democratic process." ${ }^{16}$ Few have launched a frontal attack on the principle that political responsibility is the crucial ingredient for the making of public policy in a democratic state. Rather, the most sophisticated approach has been to establish that Congress and the Executive, the so-called political branches of our government, are by no means as democratic as standard belief would hold and that the Court is much more subject to the popular will than conventional wisdom would grant. According to this view, analysis based on observations such as De Tocqueville's-that the legislature "represents the majority and implicitly obeys it" and that the executive "is appointed by the majority, and serves as a passive tool in its hands"17-is found to

11 Rostow, supra note 7, at 576.

${ }^{12} \mathrm{Cf}$. Miller, Some Pervasive Myths About the United States Supreme Court, 10 ST. L.U.L.J. 153,159 (1965).

${ }^{13}$ AFL v. American Sash \& Door Co., 335 U.S. 538, 555-56 (1949) (Frankfurter, J., concurring).

14 L. HANd, The Bill of Rights 73 (1958). (1891).

152 J. Burgess, Polmtical Science and Comparative Constitutional. Law 365

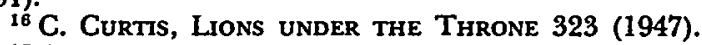

${ }^{17}$ A. De Toceueville, Democracy in America 115 (Mentor ed. 1956). 
be greatly oversimplified-"the most starry-eyed political naiveté."18 Such reasoning is described as having "abandoned most of the fictions which previously protected the power and dignity of the Court, [yet insisting] on returning to the cliches of the high school civics book when describing the political process." 19

In support of this challenge, it must be acknowledged that all of our notable governmental and quasi-governmental agencies, especially at different points in time, contain undemocratic as well as democratic features. Democracy in action is not simply a mirror reflection of popular will. Rather-as we shall soon note in greater detail-American working democracy is the grand product of the efforts and interactions of all legal and political structures in the nation, influenced at different points with varying intensities by the multitude of economic and social organizations that function outside the formal system of government. ${ }^{20}$ For reasons such as these, knowledgeable and perceptive students of the American political system such as Martin Shapiro have decried the utility of "issuing blanket condemnations of judicial action on the basis of an abstract model of democratic policy-making that does not reflect the realities of American government." In his judgment, "the Supreme Court functions within a governmental matrix of mixed democratic and nondemocratic elements," and "nothing can be solved by calling down a plague on both [the political departments and the judicial branch] because neither is selected by annual elections." Thus, "whether or not to assign certain tasks to the Justices is no more and no less a question of democracy than whether or not to assign those tasks to any other government agency. . ...21

This argument-an especially powerful one due not only to its substantial empirical premises but also to its signal theoretical force in making judicial review a legitimate element of a democratic society-merits careful consideration. There has surely been no paucity of surveys and descriptions by various commentators and journalists of the argument's empirical foundation -the general electoral responsibility of the three branches of our national government. Several scholars who have explored the consonance of the role of the Supreme Court and judicial review with our theory of government have made observations

\footnotetext{
${ }^{18}$ M. Shapiro, Freedom of Speech: The Supreme Court and Judicial Review 17 (1966) [hereinafter cited as FreEdom of SPEECH].

19 Id.

${ }^{20}$ See Chroust, Law: Reason, Legalism, and the Judicial Process, 74 ETHICs 16 (1963).

${ }^{21}$ M. Shapiro, Law and Politics in the Supreme Court 46 (1964).
} 
and references to the matter. But because the pursuit has usually been fragmentary and the conclusions often intuitive, doubts have persisted and the debate has continued. A more intensive examination of the practical operation of the American political process from the perspective of democratic theory-with particular emphasis on the specific way in which the institution of judicial review functions-is therefore both appropriate and desirable.

This inquiry first supports the proposition that the legislative branch-traditionally perceived to be the most broadly representative of all government institutions-in fact operates undemocratically. This premise is then reappraised: the negative quality of the lawmaking process' antimajoritarianism and its consequences for judicial review are explored; Congress' institutions are reviewed in a more balanced fashion; and the role of the executive is examined. Finally, the political accountability of the Supreme Court is assessed and weighed against that of the elected branches.

\section{The Defective Character of Congress' Majoritarian RESPONSIBILITY}

\section{A. The Process of Election and Inter-election Representation}

If there is any single axiom that describes the Congress, it is that neither the method for selection of its members nor its actual modes of behavior result in the automatic translation of the majority will into detailed legislation. As with all representative legislative bodies, "neither elections nor interelection activity provide much insurance that decisions will accord with the preferences of a majority of adults or voters." 22 The result is the possibility, indeed not infrequently the actuality, of minority control over the making of government policy.

To begin at bedrock, since members of both houses of Congress are elected from geographical districts rather than at large, it is at least theoretically possible (assuming a particular distribution of voter interests among the states and districts) that, even at the very moment the successful candidates assume office, they represent the views of but a small fraction of the electorate. ${ }^{23}$ The venerable art of gerrymandering in the crea-

22 Preface to Democracy, supta note 1 , at 131.

${ }^{23}$ For a mathematical demonstration of control by $25 \%$ of all voters plus one additional voter under simple majority voting, see J. Buchanan \& G. Tullock, The Calculus of Consent 220-22 (1962). 
tion of legislative districts-performed nationally and locally throughout our history of representative government and yet to be constitutionally condemned (at least not by a holding of the Supreme Court in any specific instance, even a racial one ${ }^{24}$ )-has been nurtured with this knowledge.

But even when we assume a normal dispersal of constituent interests, the election of lawmaking representatives produces no more than a very crude approximation of majority rule. Elections occur only intermittently, thus permitting the once coincident views of representative and constituent to drift apart. Nonetheless, periodic rather than constantly recurring elections are obviously required for reasons of efficiency and practicality. Such a pattern is necessary to achieve effective and stable government and to afford legislators some opportunity for independence - to permit them to use their ability and experience to educate and lead popular opinion, and to empower them at least partially to perform the role of "Burkean Trustee" rather than "Instructed Delegate" (a topic to be addressed in more detail shortly). But none of this denies the resulting imperfection in respect to the theory of pure majoritarianism.

That the people go to the polls only occasionally is, however, but a minor cause of the failure of elections to assure majority rule. More importantly, in contrast to the direct or participatory democracy of the town meeting, it is inherent in the system of representative government that the electorate must buy its political representation in bulk form. The voter is invariably offered only a few candidates (rarely more than two who have any realistic chance of being elected) to reflect his will on the myriad issues, large and small, that must be resolved in the operation of day-to-day government. Hardly ever will a candidate share all the preferences of an individual elector. Given the alternatives, agreement with a candidate on most matters will be a sufficient reason to vote for him; differences regarding a few issues, perhaps even some of real concern to the voter, will not ordinarily cause him to withhold his support for a nominee. Thus, the hypothetical meticulous elector will, either overtly or implicitly, list the issues he considers germane, assign them varying weights depending upon his intensity of feeling, and cast his ballot for that entrant whose projected score comes closest to his own. The more casual voter-and, unfortunately, in all likelihood the more typical one-will rest his judgment on some less refined basis,

${ }^{24}$ But of. Gomillion v. Lightfoot, 364 U.S. 339 (1960). 
broadly ranging from the candidate's party affiliation to his personal acquaintance with the voter. But whichever nominee is finally settled upon, the voter's choice is necessarily a highly qualified one.

Further, the larger the constituency and the broader its political base, the more accentuated this factor becomes. Thus, the major political parties in the United States submit their basic policy positions to the electorate at wholesale. In the absence of a truly extraordinary situation, they solicit support not for a full complement of specific, detailed issues but rather for candidates who run on the basis of either an integrated proposed platform or total past performance. They seek to build or maintain an electoral majority composed of people who have similar views on many questions, but they recognize that these same people will have conflicting views on other questions.

To make the same point in another way, every aggregate of American citizens large enough to constitute a majority of voters is necessarily a rather heterogeneous collection of individuals and groups who may agree on some matters but are sure to disagree on others. No group of like-minded citizens can ever win a national election merely by mobilizing themselves and others who think exactly the way they do. To win national elections, even to win influence over national policies, every group must participate somehow in the politics of coalition building. To be sure, it can pursue its own goals; and it must engage in conflict; but it must also conciliate, compromise, negotiate, bargain-and in the process often forego its lesser goals for its greater objectives. ${ }^{25}$

As a consequence of this kind of averaging and compromising in selecting a delegate, as well as of the fact that disagreements on particular issues frequently occur within a single party, there is simply no guarantee in representative government that a legislative vote on any single matter will produce the same result as would a popular referendum, even assuming equal knowledge and interest of all participants in both instances.

The electorate itself contributes another important element to the flawed reflection of majoritarianism in the legislative branch. Empirical studies confirm the widely held intuitive judgment that many citizens know little and care less about

${ }^{25}$ R. Dahl, Pluralist Democracy in the United States: Conflict and Consent 455-56 (1967) [hereinafter cited as PluRalist DEMocracy]. 
particular candidates and issues and that no majority preferences are discernible on the overwhelming number of issues decided by legislators. ${ }^{26}$ In respect to what professional and concerned observers of government would consider to be both major questions of public policy and minor matters of detail, a distressingly large percentage of voters is almost totally uninformed. As a result, they lack awareness of many, if not most, of their representatives' viewpoints on policy issues. ${ }^{27}$ This state of affairs has been exacerbated by the complexity of various congressional procedures and especially by the opportunity for anonymous voting which permits legislators to obfuscate and conceal the positions they hold and the actions they have taken on many issues.

American voters often cast their ballots for congressional candidates not on the basis of the issues or the candidates' voting records, nor even on the ground of major party affiliation, but rather on the basis of their perception of how diligently the candidate has attended or will attend to his duties-with particular emphasis on whether and how well the legislator has serviced the various requests of the voter himself or of other constituents for aid in dealing with the bureaucracy of government. ${ }^{28}$ It is these conditions that go far in explaining how the majority of a particular district may vote for a President, Senator and Representative-not to mention varied state and local officers-none of whom agree with one another regarding most prominent issues of public policy.

Furthermore, once a representative takes office, there are severe limits on the extent to which he may be depended to reflect accurately the majoritarian preferences of his constituency. The threat of reelection challenge may not be a significant force, for the reelection process cannot be expected to be any more discriminating than that of original election. Apart from this, the legislator's information respecting the desires of

${ }^{26}$ See, e.g., A. Campbell, P. Converse, W. Miller \& D. Stokes, The American Voter (1960); Dexter, The Representative and His District, in New Perspectives on THE House of Representatives 3 (2d ed. R. Peabody \& N. Polsby 1969) [hereinafter cited as New Perspectives]; Miller \& Stokes, Constituency Influence in Congress, 57 Am. PoL. Scr. REv. 45 (1963) [hereinafter cited as Constituency Influence]. See generally V. KeY, PubLIC OpINION AND AMERICAN DEMOCRACY (1967); Rothman, Individualism, Indecision and Indifference, 35 MARQ. L. REv. 219 (1952).

${ }^{27} \mathrm{~A}$ recent Gallup pole indicated "that $57 \%$ of Americans cannot name their congressman, and only $19 \%$ can cite a single thing he has done." TIME, Jan. 15, 1973, at 17.

${ }^{28}$ See Special Comm. on Congressional Ethics, The Ass'n of the Bar of the City of N.Y., Congress and THE Public Trust 10-15 (1970) [hereinafter cited as Congressional EThics]. 
his general constituency-at least as to some matters-is highly imperfect. One careful study of this question, "which compared the views and voting records of one hundred sixteen Congressmen in 1958 with the views of their constituents, revealed a surprisingly low relationship between the majority attitude in each district on social welfare and foreign policy and what the Congressman from that district thought was the majority view among his constituents." 29 In sum, legislative enactments frequently deal with subjects of indifferent or indecisive electorate concern.

\section{B. The Lawmaking Machinery in Operation}

\section{The Congressional Structure}

The most serious antimajoritarian forces in the congressional system are not found in the system of elections and interelection devices to assure trustworthy representation, however, but in the structure and inner workings of the legislative process itself. At the apex, the bicameral construction of Congress arms any minority that can gain control of one chamber with peculiar influence in impeding popular will. ${ }^{30}$ More importantly, the structure of the Senate ensures that certain groups representing a minority of the national population may constitute a majority.

The Senate is composed of two legislators from each state who have equal voting power irrespective of their state's population. This potentially permits senators who represent about fifteen percent of the national citizenry-and who were voted into office by just more than half of that number-to comprise a voting majority, able to overrule the preferences of senators representing eighty-five percent of the population. This arrangement, constitutionally ordained and unchangeable without the consent of the states themselves, has caused the Senate to be labelled as "perhaps the worst 'rotten borough' system in the democratic world."31 Furthermore, the constitutional scheme of staggered elections for members of the Senate compounds the effort required of the people who wish to obtain a reversal of its policies. The House of Representatives' members are elected

${ }^{28}$ Pluralist Democracy, supra note 25, at 134 (citing Constituency Influence, supra note 26 , at 52 ).

${ }_{30}$ This capability is augmented by the authority of the executive veto over legislation, which may nullify the vote of substantial majorities in both houses.

31 D. Spitz, Democracy and the Challenge of Power 79 (1958). 
from districts whose populations closely approach the one manone vote status mandated by the Supreme Court when it interdicted malapportionment in $1964 .^{32}$ Nonetheless, its constitutional organization guarantees. each state at least one legislator despite the fact that several states have a significantly smaller population than the average congressional district. ${ }^{33}$ In addition to these structural assymetries, each chamber contains a raft of devices and practices that undermine fulfillment of true majority rule.

\section{Filibuster}

The obstructional advantage for a minority in the filibuster and the burdensomeness of the two-thirds vote required for cloture is obvious. The filibuster is a device no longer used solely by southern obstructionists to halt civil rights advances; it has been employed more recently by liberals to thwart such programs as the supersonic transport and the antiballistic missile. In addition, the technique's potential for thwarting majority will is compounded when the minority supporting the filibuster is already overrepresented by its votes in the Senate.

\section{Congressional Committees}

The critical role played by congressional committees and subcommittees in modern times derives from the practical impossibility of each legislator giving intensive consideration to the myriad consequential measures brought before him. The ostensible purpose of the committee system is to enable selected members to devote the time and energy required for mature and detailed review of proposed legislation, and to afford different congressmen the opportunity to develop specific expertise in designated areas. The committees were conceived to investigate and determine the need for legislation, study the alternatives, shape proposals for presentation to the whole body, and make recommendations. Over the years, this design has been grandly executed. Because of the extreme complexity of the great number of issues confronting Congress, as well as the incredible demands that are made on mid-twentieth century congressmen (especially in regard to reelection campaigning and "servicing" constituents), ${ }^{34}$ the strength of many committees in determining

\footnotetext{
${ }^{32}$ Wesberry v. Sanders, 376 U.S. 1, 18 (1964). House.

${ }^{33}$ Additionally, the same states are often overrepresented in both the Senate and the

${ }^{34}$ See Congressional Ethics, supra note 28, at 7-12.
} 
crucial questions respecting the detail and timing of legislation has become enormous.

Two specific examples should suffice to illustrate the power wielded by committees:

-The House Committee on Ways and Means

originates all laws raising revenue, including tax laws; laws regulating foreign trade (because of their tariff aspect); and laws pertaining to the social security system (including medicare). Because of the complexity of the bills this committee writes and because of the temptation that exists for congressmen to add special exemptions and provisions to tax bills, legislation originating in the Ways and Means Committee normally comes before the House under rules of debate that forbid amendments. ${ }^{35}$

In 1962, a group of Democratic representatives defeated the bid of one of their southern colleagues for a seat on Ways and Means because they "believed that the fate of President Kennedy's trade program, of his tax program, and of the Medicare bill might be at stake in that single assignment." 36

-The House Committee on Appropriations "is regarded as something of a law unto itself, even within the House." ${ }^{37}$ Its dozen subcommittees scrutinize budget requests for the financing of all government programs and are largely joined in the common effort of guarding the fisc. In the period 1958-1965, they reduced more than one quarter of all desired expenditures by more than twenty percent and over half by more than five percent, despite the near-unanimous view of executive officials interviewed that a five percent decrease must be considered "serious" and "harmful to the operation of [one's] bureau (or department)."38 These subcommittees "may effectively nullify the expressed will of Congress by refusing to appropriate money authorized by law" and their decisions "are rarely challenged in full committee." The whole committee "has privileged access to the floor" and "rarely releases its reports before the day on which debate is to be held. As a result, few

${ }^{35}$ N. Polsby, Congress and the Presidency 77-78 (2d ed. 1971). See generally J. Manley, The Politics of Finance: The House Commitree on Ways and Means (1970).

${ }^{36}$ Fenno, The Internal Distribution of Influence: The House, in The Congress aND AMERICA's Future 52, 64-65 (D. Truman ed. 1965).

${ }^{37} \mathrm{~N}$. PoLSBY, supra note 35, at 122.

${ }^{38}$ R. Fenno, Congressmen in Committees 195-96 (1973) [hereinafter cited as Congressmen in Committees]. 
congressmen are inclined to challenge the committee's united front on the floor. Almost always the committee gets its way." 39

It is incontrovertible that few, if any, congressional committees are either microcosms of the entire Congress or reflective of the views of the electorate as a whole. Quite to the contrary, a highly significant consideration for deciding who is assigned to what committee-if not the most powerful factor-is the special (often parochial) interest of the aspiring congressman in the subject area of the committee's work. ${ }^{40}$ The frailty of the representative character of the committees is accentuated by the influence from within held by less than a majority of their members. Even a medium-sized minority can prevent a bill they oppose from emerging-_"the number and variety of objections they can raise is quite staggering." 41

\section{Committee Chairmen}

The chairmen of the various committees have traditionally occupied the real seats of power within the committee system. Through their agenda control, they have been able to determine when and whether bills should be considered by the full committee. In their committee executive role, they have been able to decide when and whether to call meetings at all. By their authority to select the committee's professional staff, conservative chairmen have been able to blunt the thrust of a committee composed mainly of liberals. The same result has been accomplished by skillful appointment of members of subcommittees, to which the chairmen have had the power to refer various bills. The chairmen have been empowered to decide whether particular investigations should be launched, whether and when hearings should be held, and who the witnesses should be. When bills are reported from committees, the chairmen have managed their consideration on the floor. In the House, where debate is limited, the chairmen have had the prerogative to open and close debate, allot the speaking time, and move the previous question whenever they think it appropriate. When bills that have been carried in each house go to conference, it has been the respective chairmen in each chamber who have been the bills' principal managers in the Conference Committee.

Again, just two examples of the longstanding authority of

${ }^{39}$ N. PolsBy, supra note 35 , at $124,126$.

${ }^{10}$ Congressmen in Committees, supra note 38; Jones, The Agriculture Committee and the Problem of Representation, in New PERSPECTIves, supra note 26, at 155.

${ }^{41} \mathrm{~N}$. Potsby, supra note 35 , at 98. 
these "lord-proprietors"42_reported by Douglass Cater in the mid 1960's-are necessary to suggest the limits to which this power may extend:

-Representative Otto Passman, Chairman of the House Appropriations Subcommittee on Foreign Operations,

is a professed enemy of the foreign aid program which he oversees. . . . Regularly he and his little subcommittee cut deeply into the sums already authorized by Congress. Just as regularly, the full Appropriations Committee, whose chairman shares Passman's hostility toward foreign aid, leaves the cuts untouched. The full House has made restorations only twice, both in the military-assistance categories. During the annual ritual, the President turns desperately to the Senate for more substantial help only to watch the effects be whittled away again by Passman's influence on the Senate-House Conference. ${ }^{43}$

- Representative Harold Cooley, Chairman of the House Agricultural Committee,

rules the nation's sugar economy. ... [He] works out the schedule of quotas. . . . Because the Sugar Act contains an excise tax, Cooley asserts the Constitutional prerogative of the House of Representatives to initiate all revenue measures. Because the legislation is highly technical, he claims that only his committee is able to cope with it. Within the committee itself, whose thirty-five members compete in their concerns for cotton, tobacco, wheat and the other commodities, a skillful Chairman dominates by playing off one interest against another.

It permits him remarkable discretion. In reviewing the sugar quotas, Chairman Cooley has had the habit of receiving the interested parties one by one to make their presentations, then summoning each afterward to announce his verdict. ${ }^{44}$

Despite their nationwide lawmaking impact, committee chairmen have operated quite independently of the reins of national political responsibility. Traditionally selected on the basis of seniority-a custom, it is ironic to recall, instituted originally as an antidote to the antimajoritarian tactics of a

12 G. Galloway, The Legislative Process in Congress 289 (1953).

43 D. Cater, Power in Washington 149-52 (1964). See generally R. Fenno, The POWER OF THE PURSE (1966).

14 D. CaTer, supra note 43, at 17-19. See also Jones, supra note 40. 
repressive leadership - these congressional hierarchs have thus invariably come from a limited number of safe districts (preponderantly in the South when the Democrats have controlled Congress). Whatever their accountability to their local constituencies, their immense influence is in disharmony with the democratic precept of majority rule.

\section{Party Leaders}

The party leadership in both houses has also occupied a key position in the congressional power structure. The longinstitutionalized social dynamics of Congress have led American legislators-with just a few maverick exceptions-to set a high value on "getting along" internally. This means keeping their vote in tune with the expressed wishes of the leaders of their party as often as they deem possible. Even the committee chairmen realize that they cannot ordinarily overcome the active opposition of the leadership and that they almost always need at least its passive support to get laws enacted.

But neither does the crucial function of the party leadership guarantee majority rule. Much like committee chairmen, the leaders' immediate base of political responsibility is not nationwide, but within a single state or congressional district. ${ }^{45}$ Their ascension, while not strictly linked to seniority, usually depends upon the longevity afforded by a safe constituency; once they have attained their positions, apart from extraordinary circumstances, it is not national popular opinion but only age or intense peer dissatisfaction that can dislodge them. ${ }^{46}$

\section{Conference Committee}

No description of the antimajoritarian force of the committee system and party leadership in both houses of Congress would be complete without an examination of the Conference Committee-the unique device that effects reconciliation between the different versions of legislation on the same subject enacted by the House and the Senate. Appointments to this committee are formally made by the presiding officer in each house, but the wishes of the chairmen of the respective committees that originally considered the legislation are normally re-

45 See generally Truman, Federalism and the Party System, in Federalism: Mature and EMERGENT 115 (A. Macmahon ed. 1955).

${ }^{46}$ See generally Peabody, Party Leadership Change in the United States House of Representatives, 61 AM. PoL. SCr. REv. 675 (1967); Polsby, Two Stralegies of Influence: Choasing a Majority Leader (1962) in New Perspectives, supra note 26, at 268-69. 
spected. This not infrequently results in conference members who are personally opposed to key provisions in their own chamber's version of the bill, notwithstanding the fact that their function is nominally to support that version. Since the conference compromise report that is returned to each house may not be amended and must be either totally accepted or totally rejected, the conferees potentially possess vast power to eliminate critical provisions; and both they and other congressmen are presented with a peculiar opportunity to frustrate months of prior legislative effort. Several examples demonstrate the significance of the technique:

-Sophisticated liberal members of the House, realizing that the House of Representatives tends to be more conservative than the Senate, often make no attempt to insert liberal provisions into House measures initially but may arrange for them to be put into the Senate version of the bill. In this way they avoid the strong possibility that the House of Representatives will explicitly reject provisions they are interested in. Once there is such an explicit rejection in the House, it is very difficult to pass any conference report that includes the offending language, because conservative House members will make much of the fact that the House has already rejected the provisions of the bill. Thus the technique is to see that the liberal provisions are introduced on the Senate side and then make every effort to assure that the combined bill that comes out of the conference has predominantly Senate provisions in it. ${ }^{47}$

- In 1970,] on the controversial bill to continue federal funding for the supersonic transport plane, the House had voted to authorize $\$ 290$ million, while the Senate refused to authorize any financial assistance. Yet the conferees "compromised" at $\$ 210$ million after a brief conference. Of the seven Senate conferees, four had voted to provide federal funding for the aircraft, and one, Senator Warren G. Magnuson (D-Wash.), a staunch SST-supporter, openly declared before the conference agreement was reported that he was still seeking the full $\$ 290$ million. ${ }^{48}$

-In 1962, "[a]fter winning overwhelming approval in both Houses, aid to higher education was killed" because of the

${ }^{47} \mathrm{~N}$. PolsBY, supra note 35, at 106-07.

48 Hopkins, Congressional Reform: Toward a Modern Congress, 47 Notre Dame Law. 442,501 (1972). 
conflicting views within the Conference Committee, despite the fact that either the House or Senate version was acceptable to the President. ${ }^{49}$

These illustrations may be especially poignant ones, but they are not wholly atypical. "[T]he archaic ways and the often dictatorial-like powers of conference committees"50 -as they are described by a formerly active Senate reformist, Albert Gore of Tennessee-contradict majority will in the halls of Congress.

\section{Interest Groups}

In exploring the assortment of undemocratic forces at work in the legislative process, some recognition must also be given to the influence held by what are popularly known as "interest" or "pressure groups." There is a sizeable literature describing and appraising the complicated and potent governmental role that the various types of factions falling under this label have assumed. ${ }^{51}$ More will be said shortly about some of these kinds of groups. At this point, it is enough to note the well identified existence of one set-the organized lobbies. Although knowledge of the nature, frequency and success of the various methods that they employ is far from complete, ${ }^{52}$ it is generally agreed that by transmitting pertinent information to key lawmakers, by skillfully and selectively applying pressure at critical points in the system, and by expending massive sums of money-not infrequently in an abusive, if not actually criminal, manner-they are able to exercise power well beyond the force of the numbers of people they represent.

These lobbies do not limit their efforts to the offices of particular legislators and relevant congressional committees. They also effectively pierce the bureaucratic maze of the executive branch and of the independent regulatory agencies which, because of their extensive rulemaking authority, and especially because of their status as the source of many of the programs considered by Congress, play an important part in the national legislative process. Conventional belief, supported by at least some hard and often disconcerting empirical evidence, holds that specific lobbies have been particularly successful on this latter front-for example, the Farm Bureau in the Department

\footnotetext{
${ }^{49} \mathrm{D}$. CATER, supra note 43 , at 9-10.

${ }^{50}$ Gore, The Conference Committee: Congress' Final Filter, The Washington Monthly, June, 1971 , at 43 .

${ }^{51}$ See, e.g., D. Truman, The Governmental Process (1951).

52 See generally R. Bauer, I. Pool \& L. Dexter, American Business and Public Policy: The Politics of Foreign Trade (1963).
} 
of Agriculture; the "military-industrial complex" in the Department of Defense; the National Association of Manufacturers in the Department of Commerce; the railroads in the Interstate Commerce Commission; the oil and gas industry in the Federal Power Commission; and even certain foreign governments in parts of the Department of State. Indeed, it is often charged that some government agencies have fallen captive to the very private interests supposed to be the subjects of their regulation. ${ }^{53}$

To cap all of this, the interaction among the lobbies, the executive and administrative bureaus, and the pertinent legislative committees is seen as producing enormous political clout. Described by one observer as "[g]overnment by whirlpools," 54 it has led another to conclude:

Since the bureau generally drafts initial legislation and the committee has paramount powers over the bill once it reaches Congress, these alliances are of tremendous importance. They tend to protect subordinate, and frequently group dominated, segments of government from whatever democratic and broadly popular control one might expect from Congress as a whole and from the President. ${ }^{55}$

\section{A Summary and Qualification}

The preceding picture of the national lawmaking process reveals anything but a system that simply articulates some readily identifiable popular will. Rather, the business of legislating solutions to the exceedingly difficult and intricate problems confronting American society is seen as a complicated interplay among nonmajoritarian based organs of power within the government and various organized vested interest groups without, which are continually engaged in activities of consultation, negotiation and conciliation. At best, the voice of the people is recognized as an often minor factor interacting with a multitude of other forces.

If this were a complete and accurate portrayal, unburdened by serious ambiguities, the task of legitimately fitting the Supreme Court and judicial review into the working machinery of - American democratic society would not be a very uncomfortable one. But the foregoing description of the antimajoritarian nature of the federal legislative scheme has been one-sided and, thus, (1955).

${ }^{53}$ See genetally M. Bernstein, Regulating Business by Independent Commission

3 E. Griffith, Congress: Its Contemporary Role 127 (1956).

${ }^{55}$ Freedom of SPEECH, sufra note 18, at 23. 
distorted. True enough, "there can be no automatic and blanket equation of Congress or the Executive branch with the voice of the people," 56 and "[d]emocracy conceived populistically simply does not comport with political reality." 57 Nevertheless, as will soon be shown, the lawmaking process is greatly more responsive to constituent will and much more aligned with traditional democratic precepts than the prior recitation would lead one to believe.

\section{The "Negative" Quality of the Lawmaking Process's ANTIMajoritarianism}

In comparing the undemocratic features of our national legislative system with those of the power of judicial review-a contrast undertaken for the purpose of examining the latter's validity in the American plan of democracy-one central factor bears emphasis at the outset. In the main, the effect of judicial review in ruling legislation unconstitutional is to nullify the finished product of the lawmaking process. It is the very rare Supreme Court decision on constitutionality that affirmatively mandates the undertaking of government action. To make the point in another way, when the Supreme Court finds legislative acts unconstitutional it holds invalid only those enactments that have survived the many hurdles fixed between incipient proposals and standing law.

The significance of this evident fact for our purposes is that most of the antimajoritarian elements that have been found in the American legislative process-both quantitatively and qualitatively-are negative ones. They work to prevent the translation of popular wishes into governing rules rather than to produce laws that are contrary to majority sentiment. Conceding the validity of the broad contention that the national lawmaking machinery contains a host of multifaceted undemocratic features, it is critical to recognize the primary consequence-and the most frequently voiced major objection-that follows. It is not that far-reaching laws promulgated by the legislative system are opposed by a predominant segment of the populace, but rather that Congress too often refuses to enact solutions supported by national majorities.

The phenomenon of negativism operates in the lawmaking process at several levels. The effect of the bicameral legislature is

${ }^{57}$ Kommer, Professor Kurland, The Supreme Court, and Political Science, 15 J. Pub. L. 230, 242 (1966). 
to require the mustering of two separate majorities to carry a bill while permitting either body to frustrate its passage. Thus it is true, as noted earlier, that senators representing only fifteen percent of the population may hold sway in the upper house; but their real impact (as is obviously the case with the filibuster as well) is to halt ultimate action rather than facilitate it. For the enactment of law also requires the concurrence of the lower chamber-and the House of Representatives in recent years has become well-known as a frequently uncompromising "naysaying" body to measures passed by the Senate. Furthermore, within each legislative chamber, the ability of the committees and their chairmen and minority members-and frequently of the lobbies and other interest groups as well-to circumvent the majority will of the assembly is most saliently manifested in obstructing the process rather than in making laws. The more formidable task usually is not to stall or defeat a proposal but to organize the requisite support among the dispersed powers so as to form a coalition for its passage. This is all the more true when the issue at hand is one of real public visibility and concern, causing a legislator to be especially wary of bargaining away or compromising his vote. Beyond all this, the force of the executive veto in rendering congressional majorities ineffectual also operates to deny rather than decree legislation.

Thus, although exceptions exist, "[a] distinguishing feature of our system, perhaps impelled by heritage of sectional division and heterogeneity, is that our governmental structure, institutional habits, and political parties with their internal factional divisions, have combined to produce a system in which major programs and major new directions cannot be undertaken unless supported by a fairly broad popular consensus. This normally has been far broader than 51 percent, and often bipartisan as well." ${ }^{8}$ Having underscored this point does not end the subject, however. By no means are all of the undemocratic aspects of the federal legislative process negative in character. Further inquiry remains to be undertaken. But two basic matters should be acknowledged. First, the crucial issue is not simply whether the national legislative process is, all in all, more electorally responsible than the federal judiciary, but rather whether the institution of judicial review is compatible with American democratic theory and practice. Second, there is substance to the message that

38 R. Dixon, Democratic Representation: Reapportionment in Lai: and Poltics 10 (1968). 
when the Supreme Court, itself without conventional political responsibility, says "thou shalt not" to acts of Congress, it usually cuts sharply against the grain of majority rule. The relatively few laws that finally overcome the congressional obstacle course generally illustrate the national political branches operating at their majoritarian best while the process of judicial review depicts that element of the Court's work and that exertion of federal authority with the most brittle democratic roots. ${ }^{59}$

The case is not as persuasive when it is the conduct of judges or, even more often, of lower echelon administrative officials that the Court finds constitutionally objectionable $e^{60}$-for example, a rule of court respecting the admission of illegally seized evidence, a local police practice regarding lineups, a state welfare board procedure governing the termination of benefits, a Civil Rights Commission regulation concerning confrontation of adverse witnesses, a Navy Department program dealing with security clearance for employees on bases. Indeed, at least in recent experience, measures such as these have comprised the major segment of the Court's constitutional adjudications. But it should be recognized that all these policies are promulgated by public officers who, though not commonly subject to direct recall at periodic elections, obtain and hold their positions under the authority of other government officials who are immediately responsible to the people. Further, it is fair to observe that the bulk of these administrative practices, especially those of law enforcement agencies, command broad popular support. If the people or their elected representatives disapprove of their continuance, these policies may be altered by ordinary legislation or directive. Although the forces of inertia that operate in the lawmaking process make change no automatic endeavor, it is still much less difficult for a majority to reverse an existing administrative policy through commonplace legislative methods than it is to reinstate it after a judicial declaration of invalidity.

\section{The Majoritarian Responsibility of Congress ReEXamined}

From a less adversary perspective, it seems clear that Congress' antimajoritarian ingredients are not as forceful in operation-even in obstructing legislation-as they were earlier made out to be.

${ }^{59}$ Although no detailed examination of the legislative systems in the states and their political subdivisions has been ventured here, the same conclusion appears to have substantially similar merit in respect to the Court's overturning the laws they produce.

${ }^{60}$ This is true whether the officials work on the municipal, state or federal level. 


\section{A. The Process of Election and Inter-election Representation}

American history has shown the mathematical possibility of true minority control of legislatures through districting without gerrymandering to exist in theory only. Moreover, even assuming its continuance without specific judicial intervention, gerrymandering itself, although not just a theoretical construct, is "an increasingly risky enterprise" for state legislatures to undertake because of " $[t]$ he great mobility of the American people, the accelerating pace of socioeconomic change and the increasing uncertainties in the futures of both major parties."61

The criticisms of the limited choices offered the electorate by individual candidates and political parties, of voter ignorance and apathy regarding nominees and issues, and of elected representatives' not reflecting majority will are, however, very serious ones. First, regarding the major political parties and their nominees, it may be "that the removal of a government carries no necessary assurance that its successor will proceed in a markedly different direction;" ${ }^{2}$ but this does not prove that the democratic ideal is defeated by the American system of two principal parties submitting candidates for offices. Nor is such a claim substantiated by the fact that "[a]ll too often the major political parties are agreed on a specific measure or policy."63 For the chances are far greater than not that the policy at issue is one on which most of the electorate, as well as the parties, are in accord. The available empirical evidence-tentative as it may be-indicates that when the average American voter casts his ballot along party lines, he is fairly knowledgeable about which party better reflects the positions he holds. ${ }^{64}$

Thus, as Robert Dahl, one of the most eminent scholars of American politics, concludes, "What happens if a party responds more to its leaders than to the voters? The answer seems obvious: It will probably be defeated in elections-if the other party is closer to the views of the electorate." 65 Even presidential elections have not infrequently turned on a single great question, or a closely bracketed set of critical issues, over which the parties or their nominees have been divided-as would have been attested, for example, by President John Adams in 1800, President John

\footnotetext{
61 Auerbach, stpra note 10 , at 65 .

${ }^{62} \mathrm{D}$. SPITz, supra note 31 , at 74.

${ }^{63} \mathrm{Id}$.

${ }^{64}$ See Pomper, From Confusion to Clarity: Issues and American Voters, 1956-68, 66 AM. Pol. Sci. Rev. 415 (1972). Cf. V. Key, The Responsible Electorate 7-8 (1966).

${ }^{65}$ Pluralist Democracy, supra note 25 , at 248. See generally id. 243-57.
} 
Quincy Adams in 1828, William Jennings Bryan in 1896, President Taft in 1912, Governor Landon in 1936, Senator Goldwater in 1964 and Senator McGovern in 1972. Perhaps the citizenry cannot always "secure the reversal of a particular measure," but they usually can "readily overturn [or reject] fundamental policies,"66 if they feel strongly enough about them-as President Johnson manifestly perceived in 1968.

That many citizens are ill-informed about the complex policies and detailed issues confronted by their representatives, thus affording the legislators broad discretion and independence in lawmaking, need not be as incompatible with majority rule as it is made to sound. The specific details of most solutions ultimately passed upon by the legislature cannot, in the nature of things, be in the minds of the voters at the time of the elections. Further, a great many of the legislative issues that do not concern large numbers of voters probably should not. Therefore, it is not inconsistent with majority rule to permit these categories of decisions to rest within the judgment of the legislator himself, even if his verdict is influenced significantly by pressure groups. On such issues, the latter may well be the most efficient representatives of the generalized majority interest. Even if not, to characterize this as minority rule closely parallels finding pervasive minority rule in the fact that a substantial portion of the eligible population-indeed, often exceeding fifty percent-chooses not to vote at all on election day.

More importantly, some empirical surveys tend to confirm the intuitive notion that voters elect candidates, and representatives act on the assumption that they have been selected, for dual purposes: citizens choose legislators who they believe will, when possessed with the requisite knowledge concerning alternative courses, vote the citizens' general preferences, or operate as "Instructed Delegates"; but the electorate also supports those candidates in whose independent values and judgments they have confidence, implicitly authorizing these representatives to vote their own perception of the public good, or to act as "Burkean Trustees." 67 Whether in a given situation the elector intends his representative to perform as Instructed Delegate or Burkean Trustee depends mainly upon the specific issue involved and the intensity of the elector's opinion regarding it. But the hard evidence that exists tends to show that voters recognize

${ }^{66} \mathrm{D}$. SPITz, supra note 31 , at 74 .

${ }^{67}$ See Congressional Ethics, supra note 28, at 12-15; Constituency Influence, supra note 26, at 45; cf. G. Galloway, Congress at the Crossroads 320-21 (1946). 
both their unfamiliarity and incompetence regarding many policy matters and that, in consequence, they "choose to be governed by the officials elected as well as to govern through them." 68

It is less evident whether this usually inexplicit popular intention actually extends, as conceived by Hamilton, to charging "those to whom they intrust the management of their affairs" with the "duty" to disregard certain of their preferences ("every sudden breeze of passion" or "every transient impulse") on those occasions "in which the interests of the people are at variance with their inclinations ... . in order to give them time and opportunity for more cool and sedate reflection." ${ }^{69}$ But it is clear that if the people's elected guardians ignore the popular will too often, they will soon be retired. Nonetheless, the people do expect their officials to lead as well as follow and to engage in an informed dialogue with them. The fundamental difference between this educational experience conducted by legislators and, as put by Eugene Rostow, the Supreme Court Justices' acting as "teachers in a vital national seminar"70 through constitutional decisionmaking, is that the legislators, but not the Justices, may readily be deposed if the received learning is found too distasteful.

The foregoing discussion indicates that, at least at a general level, the national process for choosing legislators conforms much more closely to Madison's original conception of truly representative houses of Congress ${ }^{71}$ than to our earlier. onesided version, and that constituency policy preference on important issues is in fact a signally important component in delegate selection. Thus, for example, in 1958, Representative Brooks Hays, after lengthy service in the House, was defeated for reelection by Dale Alford, a write-in candidate. In the sample of voters in the Arkansas district surveyed, not one was unaware of either candidate. "What is more, these interviews show[ed] that Hays was regarded both by his supporters and his opponents as more moderate than Alford on civil rights and that this perception brought his defeat."72 Many additional illustrations could readily be found in the series of House and Senate-indeed, Presidential-elections in the 1960's and early 1970's that consti-

${ }^{68}$ McLaughlin, What Has the Supreme Court Taught? 72 W. VA. L. REv. 326, 335 (1970) (emphasis altered).

${ }_{69}$ The Federalist No. 71, at 459 (B. Wright ed. 1961) (A. Hamilton). (1952)

${ }^{70}$ Rostow, The Democratic Character of Judicial Review, 66 HARv. L. Rev. 193, 208

${ }_{71}$ See The Federalist No. 56 (J. Madison).

${ }^{72}$ Constituency Influence, supra note 26, at 55. 
tuted little more than popular referenda on the Vietnam war issue.

The ultimate significance of this lies, of course, in its effect on legislative policymaking. A number of empirical studies reveal that, although the matter depends very heavily on the legislative issues involved, almost all congressmen hold the firm belief that their election turns largely, if not exclusively, on how their constituents view their voting records. ${ }^{73}$ "Outraged public opinion," one inquiry concludes, "is the single most effective pressure on Congress." 74 Moreover, the studies corroborate the probable inference that the more prominent the issue and the more intense the voters' feelings, the more substantial the impact on the legislator. As put by one southern congressman in explaining his vote to unseat Representative Adam Clayton Powell: "It was either his seat or mine."

Similarly, in 1955, a number of southern congressmen, traditionally strong supporters of free trade, opposed the leadership of Speaker Rayburn and voted against reciprocal trade- "chiefly the result of the communications they received from their districts, largely from textile interests. . . . If industry and the workers in their district [were] convinced that reciprocal trade [would] hurt them, they [were] willing to go along . . .."76 The proposition, it might be useful to underline, is not that legislators bow to constituent will on each and every issue before them, nor even on all issues about which a large group of the electorate holds a discernible view. Rather, the conclusion is that distinct voter preferences on major issues do customarily prevail.

This reality is closely bound, and thus similarly responds, to a factor already mentioned as one of the antimajoritarian features of Congress: the flawed system of communication between voters and legislators. Whatever the deficiencies in information transmission, if the issue is big enough and the electorate feels strongly enough, the message reaches Washington loudly and clearly. It is also important to observe that the clarity of the picture from the Capitol has been heightened by several recently inaugurated disclosure devices. Among these are the abandonment of the Senate rule forbidding committees from drafting

${ }^{73}$ See, e.g., Ingram, The Impact of Constituency on the Process of Legislating, 22 W. PoL. Q. 265 (1969); Constituency Infiuence, supra note 26. See generally D. MACRAE, Dimensions OF CONGRESSIONAL VOTING 278 (1958). For a similar conclusion reached non-empirically, see G. Galloway supra note 42, at 210-12; V. Key, American State Politics 152 (1956).

is Congressional Ethics, supra note 28, at 33.

${ }^{75} \mathrm{Id}$.

${ }^{76}$ Dexter, supra note 26, at 3, 22. 
bills in public, ratifying the decision of a majority of the members of several of its committees to conduct open mark-up sessions; the adoption of an even more promising House of Representatives reform measure stipulating that all hearings (apart from those dealing with national security or the personal affairs of individuals) must emerge from behind closed doors unless a majority of committee members publicly votes otherwise, followed by decisions of a number of the most influential committees in the lower chamber to hold almost all their deliberations openly; ${ }^{77}$ and the new House of Representatives requirement that all teller votes be recorded and published, thus ending the use of anonymity to conceal the way members vote. ${ }^{78}$

The gap in communications that exists between constituents and congressmen has a broader significance in the examination of whether legislators attend to voters' policy desires; its pertinence intersects to a degree with the matter of pressure group influence, as well. As just noted, the empirical surveys divulge that congressmen feel that their voting records will contribute significantly to their election and thus they are strongly influenced by their perception of their constituents' preferences. But this does not assure undeviating fulfillment of majority sentiment, since, as one widely-cited study concludes, congressmen tend "to overestimate their visibility to the local public, a tendency that reflects the difficulties of the Representative in forming a correct judgment of constituent opinion," and since most congressmen's understanding of their constituents' preferences is often "heavily biased" because "[t]he communication [they] have with their districts inevitably puts them in touch with organized groups and with individuals who are relatively wellinformed about politics."79

This should not, however, be viewed as an unhealthy development in a democracy. It should rather be seen as being in furtherance of majoritarian representation. For regardless of the actual imperfections in legislative reflection of majority will

" See 31 Cong. Q. WeEKLY ReP. 501-04 (1973).

${ }^{78}$ The impact an alteration in the rules of procedure can have on the decisionmaking processes in Congress and on the legislative output was vividly illustrated early in the first session of the 92nd Congress, when the House, in casting its first recorded vote on the question of federal assistance for development of a supersonic transport plane, reversed its position of seven years and voted to end the controversial subsidy. There were a number of factors behind the turnabout, but foremost among them was the newly created recorded teller vote, which forced House members to take a position in the public eye.

Hopkins, supra note 48 , at 450 (footnotes omitted).

${ }^{79}$ Constituency Influence, supra note 26, at 54-55. Cf. Dexter, supra note 26. 
on some issues (and the presence of such shortcomings has been openly acknowledged throughout), they are largely ameliorated-at least in terms of democratic theory-by the fact that congressmen probably believe that they represent the preponderant views of the voters in their districts more often than they do so in practice; the important fact is that congressmen do feel obliged to respect constituents' interests. Nor is it at all unlikely that the vocal elements in the community normally reflect whatever broader citizen sentiment exists, especially on those issues on which the electors' preference has not been expressed. As has been noted, the lines of communication between Main Street and Capitol Hill are constantly improving. In any case, however clogged they may be, they are both more direct and informative than those running to the chambers of the justices of the Supreme Court. Even the recent Nadersponsored indictment of the national legislative department concludes: "For all its flaws, Congress is still the most responsive and open branch of the government."80

Furthermore, the empirical analysis by Warren Miller and Donald Stokes in their highly respected study ${ }^{81}$ indicates that the people's voice is quite distinctly understood when raised vigorously about prominent issues on which many voters hold firm opinions. In their survey, a high correlation between what congressmen thought to be the dominant opinion of all their constituents and what these views really were was found on the question of civil rights, ${ }^{82}$ which was likely the most vital issue of the time.

On the other hand, on foreign policy issues, the correlation

${ }^{80}$ M. Green, J. Fallows \& D. Zwick, Who Runs Congress? The President, Big BUSINESS, OR YOU? 95 (1972).

${ }^{81}$ Constituency Influence, supra note 26.

82 On a continuum of +1.0 to -1.0 , the correlation between real constituency attitude and the representatives' perceived constituency attitudes was 0.63 on civil rights. Id. 52, Table 1 .

The correlation between the entire constituency's actual and perceived attitudes on the matter of government social welfare was quite low- 0.17 . Id. 52. However, "detailed ... findings in this area ... show that the Representative's perceptions and attitudes are more strongly associated with the attitude of his electoral majority than they are with the attitudes of the constituency as a whole." Id. Furthermore, the data make quite plain that the majority's views on social welfare policy-a salient topic on which the long conflicting and plainly articulated views of the major parties and their candidates greatly facilitated communication between voter and representative-correlate quite highly with representatives" roll call votes. "Whereas the correlation between the constituency majority and congressional roll call votes [was] nearly +0.4 on social welfare policy, the correlation of the district majority with the non-incumbent candidate [was] -0.4 . This difference, amounting to almost 0.8 , between these two coefficients is an indicator of what the dominant electoral element of the constituency gets on the average by choosing the Congressman it has and excluding his opponent from office." Id. at 50. 
was markedly lower. ${ }^{83}$ This may plausibly be explained by pragmatic indifference, for at the time of the study (which was before Vietnam became a political byword) the evidence was that many representatives based their foreign policy votes neither on constituent preferences nor on their own instincts, but rather tended to follow the lead of the executive branch. And there is probably some justification in democratic theory for this disposition; perhaps on these far-reaching questions of distinctly national scope, the legislators felt obliged to take a special sort of Burkean stance, either responding to a perceived nationwide attitude rather than to the soundings in their districts, or deferring to presidential responsibility and expertise. Indeed, the national citizenry itself has often manifested the latter tendency, for example, by voicing general support for President Johnson in 1966 far more substantial than its concurrence with his specific actions in Indochina. ${ }^{84}$ But, as many hawkish (as well as some dovish) incumbents came to know, the dialogue between Burkean Trustee and the voters is subject to cloture-and the electorate, if it so wishes, may exercise the right of last rebuttal.

Finally, the Burkean model seems also to account in part for the fact that the safer the district, the stronger the legislator's display of independence of popular will on specific issues. ${ }^{85}$ It is surely reasonable for a continually reelected lawmaker to infer that his constituents have authorized him to exercise personal judgment with greater than normal freedom. But, once again, it is obvious that some have learned-as often in primaries as in general elections-that this liberty has its limits.

To conclude the point, no claim is here made that the votes of congressmen perfectly mirror the desires of their constituents. The conduct of legislators is complicated by a host of interactive elements. The empirical evidence is relatively sparse and undoubtedly more remains to be discovered than ever will be. But, in admittedly varying degrees, all senators and representatives are, as said by Dahl, certainly "right in thinking that they would place themselves in serious jeopardy at the polls if they were to vote counter to the views of a majority of their constituents on any matter that is salient and important to a sizeable share of the voters at home."86

83 The figure was 0.19. Compare the data supra note 82 .

st See Verba, Brody, Parker, Nie, Polsby, Ekman \& Black, Public Opinion and the War in Vietnam, 61 AM. Pol. Scr. REv. 317 (1967).

${ }^{85}$ See Davidson, Congress in the American Political System, in Legislatures IN Developmental Perspective 129 (A. Kornberg \& L. Musolf eds. 1970).

${ }^{86}$ Pluralist Democracy, supta note 25, at 135. 


\section{B. The Lawmaking Machinery in Operation}

\section{Bicameralism and Filibuster}

The particularly negative character of these mechanisms, as far as majoritarianism is concerned, has already been noted. Beyond that, it is pertinent to recognize that bicameralism actually serves democratic ends by forcing fuller and more open congressional consideration of great issues and by improving the flow of information to the electorate. The same is at least arguably, if somewhat perversely, true of the filibuster as well.

\section{Congressional Committees and Chairmen}

The committees, however, constitute more than a negative force. These power cliques, and especially their chairmen, elected but not nationally responsible, have, at least on occasion, seen their prejudices become law.

No consideration has yet been given to that bane of promajoritarian critics, the Rules Committee of the House of Representatives. For many years, this assemblage was perhaps the most effective bill stopper in the Congress. The ingenuity in recent times of its several conservative chairmen and their colleagues in delaying legislation until they struck a bargain satisfactory to themselves, but often distasteful to a majority of the House, became legendary. But, this committee has now been caught in the net of reform, mainly by a change in its composition through enlargement and attrition so that it presently approximates more closely the political leanings of the leadership of the majority party. It is no longer the signal object of scorn among those who indict the Congress as being unrepresentative. Indeed, the decline of this despotic group's influence suggests that no matter how ingrained an antimajoritarian stain in the lawmaking process may be, it is not ineradicable. Even the longstanding rule in the House of Representatives forbidding floor amendments to measures proposed by the Ways and Means Committee has been recently altered: at the request of fifty of its members, the Democratic party caucus may now demand a vote on a specific provision by the full House. ${ }^{87}$

Furthermore, there are other operative forces which limit the grip of a committee and its chairman. Even the general nay-saying ability of committees is by no means unqualified. If a

${ }^{87}$ See Hopkins, Congressional Reform Advances in the Ninety-third Congress, 60 A.B.A.J. 47,48 (1974). 
majority of either house truly desires action, it may resort to a discharge procedure to wrest a pending measure from the clutches of any of its committees. Although infrequently utilized, the threat of this method, as well as respect for the will of the body as a whole, usually prohibits committee chairmen from blocking consideration of issues deemed fundamental and limits their impact to matters of timing and subordinate policy.

The instances in which a dominant chairman legislates for the nation, such as the sugar quota affair, are exceptional. Without in any way denying the autocratic nature of such conduct or devaluing its undemocratic quality, action such as this virtually always concerns matters of specific detail and hardly ever questions of central concern. The judgment of Nelson Polsby, a leading congressional scholar, that it would be "futile" for a chairman "to promote legislation which cannot command widespread support, at least from the leadership of his own party, or from a vast majority of his colleagues on the floor," 88 may be buttressed by countless illustrations ranging the full spectrum of Congress' activities. In reference to taxation, for example, Douglass Cater reports that Representative Wilbur Mills, Chairman of the Ways and Means Committee and perhaps the most commanding figure in both houses, "argues that his primary concern must be to coalesce majority support for a bill in Committee and in the full House. The Ways and Means Chairman, he believes firmly, must guard a reputation for invincibility if his handicraft is not to be torn apart by the competing pressures." 89 Another instance relates to the amount and location of defense spending; Cater describes in detail the lengthy and painstaking process of negotiation that takes place in the quest for broad based support.90

Furthermore, the dictatorial authority of chairmen within their committees has recently been significantly diluted, to counter antimajoritarian tendencies. As a result of important reforms, clarifications and codifications in the Legislative Reorganization Act of 1970, chairmen may not obstinately refuse to convene the committee, for a majority of the members may call a meeting; ${ }^{91}$ standing committees have regular meeting days with an alternative presiding officer if the chairman is absent; ${ }^{92}$ com-

${ }^{88}$ N. PotsBy, supra note 35 , at 65 .

B9 D. CATER, supra note 43 , at 148 . For a detailed study of the operation of the Ways and Means Committee, see J. ManLeY, supra note 29.

${ }_{90}$ See D. CATER, supra note 43 , at $26-48$.

912 U.S.C. \& $190 \mathrm{a}(\mathrm{a})(1970)$.

92 Id. 
mittee hearings must generally be scheduled in advance through public announcement; ${ }^{93}$ minority members are entitled to call some witnesses, if a majority of the minority members so request; ${ }^{94}$ all witnesses must ordinarily file a written statement prior to their proposed testimony so as to alert interested legislators of the precise subject of the hearings; ${ }^{95}$ and finally, if the chairman delays in filing committee reports, a majority of his committee associates may require that it be done. ${ }^{96}$

Modifications of the procedures in both chambers for choosing chairmen and other committee members have also been substantial. Challenges to length of tenure as the exclusive criterion for chairmanship have been facilitated in the House by the caucuses of both parties, which now require that all their committee leaders be elected through majority vote of each party's full membership-by secret ballot automatically for the Republicans, and on demand of twenty percent of the party's Representatives for the Democrats. On the Senate side, both the Democrats and the Republicans recently provided that nominees for committee chairman and top-ranking member must be individually approved by the solons of the respective parties. ${ }^{97}$ Probably most important of all, newly adopted regulations bar any congressman from occupying the chair of more than one subcommittee. In addition, the rules of both House of Representatives caucuses now affirmatively state that seniority is not required as a basis for committee assignment. ${ }^{98}$ House Democrats have redesigned their system for all committee positions to assure a more equitable distribution to junior members and to prevent chairmen from "stacking" key subcommittees with hand-picked disciples; Senate Republicans have taken similar action.99

It is necessary to add that no committee potentate who had previously achieved his status through electoral longevity has yet been toppled under the new procedures. But the fact that the seniority system is no longer sacrosanct has immeasurable symbolic importance for future progress. In the judgment of one junior Representative, "there is a growing movement to set limits on the number of years a chairman can hold power."100 Although history indicates that confident predictions are risky, it

${ }^{93}$ Id. \& 190a-1(a) (1970).

${ }^{94} I d$. $\$ 190 \mathrm{a}-1(\mathrm{e})(1970)$.

${ }^{95} I d$. $\S 190 \mathrm{a}-1(\mathrm{c})(1970)$.

${ }^{96} I d$. $\$ 190 \mathrm{a}(\mathrm{c})(1970)$.

${ }^{97}$ See 31 CoNg. Q. WeEkLy REP. 69, 136 (1973).

${ }^{98}$ See Hopkins, supra note 48 , at $481-83$.

99 See 31 Cong. Q. WEEkLY REP. 279 (1973).

${ }^{100}$ Heinz, Book Review, 11 DuQ. L. REv. 743, 748 (1973). 
appears overall that the congressional committee system is due for further reforms, all more closely approaching the democratic model.

\section{Party Leaders}

One of the principal restraints on the affirmative power of committee chairmen already observed is the fact that they usually need the backing of the party leadership to enact legislation. ${ }^{101}$ But the majoritarian political responsibility of that very leadership has itself been made the subject of criticism. ${ }^{102}$ Thus, a dilemma of sorts arises. On the one hand, if the party' chieftains heed the views of their respective constituencies, then these congressional districts exert an enormously disproportionate influence on fundamental policies of nationwide import. On the other hand, if the party leaders do not abide by their electorates' preferences-and empirical data suggest this to be the case $\mathrm{e}^{103}$ - then these leaders appear responsible only to themselves.

These conditions are plausibly (albeit intuitively) reconcilable with the projection of a democratic image for the party leaders, however. To begin with-and to accept the validity of the empirical data-legislators who have reached the peaks in Congress, and who are thus peculiarly entrusted with solemn responsibility for addressing the profound problems confronting the nation and the world, are very likely to be regarded by their constituents, and to view themselves, as Burkean representatives. The authorized boundaries of their independent judgments are very apt to be unusually wide, investing them with a much greater than average margin in which to follow their own best instincts.

Indeed, their perceived constituency is probably the nation as a whole, and this political responsibility is traditionally reflected at several levels. First, in developing positions and supporting programs, they incorporate their understanding of national elections. ${ }^{104}$ Second, if it is reasonable to view the party

${ }^{101}$ Text preceding note 45 supra.

102 It should be noted, however, that the national constituency may have some indirect control over party leadership. Robert Peabody has argued that when a party suffers a bad year at the polls, its leadership is more likely to be replaced. Peabody, supra note 46 , at $687-89$.

${ }^{103} \mathrm{~A}$ recent Kraft poll found that "the voting records of ten House leaders have not reflected their constituents' views on such key issues as Vietnam, the draft and the supersonic transport" and "that very few voters in the ten congressional districts knew how their representatives had voted" on these issues. S.F. Chronicle, Aug. 25, 1971, at 10, col. 1.

${ }^{104}$ See Pluralist Democracy, supta note 25, at 288. 
leaders' congressional colleagues-who, after all, elected them to their leadership positions-as their true constituents, then by formulating policies in response to the predilections of their peers, the party leaders reflect; derivatively, the preferences of that segment of the national electorate that supported their party. ${ }^{105}$ Nonetheless, third, in seeking to persuade their congressional colleagues to advance leadership policies, they ultimately respect the members' obligations to their own constituencies. ${ }^{106}$

\section{Conference Committee}

The antimajoritarian role of the Conference Committee, the last part of the congressional committee structure examined earlier, ${ }^{107}$ also requires qualification. Its lack of affirmative capacity to insert provisions enacted by neither chamber has recently been clarified and codified. ${ }^{108}$ Wide as its powèrs may be, if its reports propose laws unsupported by the majority, they may be rejected outright or, in the Senate, filibustered. In the House, the conference report may be returned to the committee with specific instructions, thus discouraging both House and Senate conferees from venturing too far from the House bill because this may result in the House's mandating its own particular version. Members of the lower chamber may also seek to insure against restoration of a provision defeated in the House but passed in the Senate by exacting a pledge to this effect from the House conferees in exchange for the unanimous consent necessary in the House ${ }^{109}$ to expedite a bill's going to conference. Thus, a nearer view reveals closer conformity to democratic precepts.

\section{Interest Groups}

Of all the components that contribute to lawmaking in the United States, the impact upon majority rule made by the

${ }^{105}$ This explanation was suggested to me by Nelson W. Polsby. See also Fenno, supra note 36.

${ }^{106}$ Party leaders "rely mainly on persuasion, party loyalty, expectations of reciprocal treatment, and, occasionally, special inducements such as patronage or public works. But none of these is likely to be adequate if a member is persuaded that a vote to support his party will cost him votes among his constituents. For he is concerned about his own reelection. Fortunately for him, the mores of Congress, accepted by the leaders themselves, are perfectly clear on this point: His own reelection comes first." Pluralist Democracy, supra note 25, at 131. See generally Dexter, supra note 26.

${ }_{107}$ Text accompanying notes 47-50 supra.

${ }^{108}$ Legislative Reorganization Act of 1970, Pub. L. No. 91-510, § 125(b)(3), 84 Stat. $1140,1159-60$ (Oct. 26, 1970).

${ }^{109} \mathrm{~N}$. POLSBY, supra note 35, at 107. 
various interest and pressure groups and organized lobbies is probably the most complex to assess. It is indisputable that the election and actions of legislators are strongly affected by applications of pressure at a large variety of critical points in the system-whether by professional, paid lobbyists for specific economic, social or political interests; by amateurs coordinating letter and telephone campaigns; by the increasing number of "citizens' lobbies" headed by such persons as John Gardner and Ralph Nader; or by other organized or disorganized groups of people. It appears to be nearly as certain that the contention that the dominance of special interests makes American government systematically undemocratic is no more factually supportable or inherently persuasive than the argument that the total impact of pressure groups with conflicting biases magically produces a perfect majoritarian equilibrium.

As an empirical matter, the several studies undertaken suggest that the various interest groups tend to serve as effective links between voters and representatives, especially between elections; that legislators tend to respond initially by seeking to determine whether the urgings of pressure groups reflect a generally held constituent view, are opposed by a majority of their electorates, or involve a matter that is of no special concern to most of the voters in their districts; and that the lawmakers then exercise that degree of judgment with which they feel empowered-but almost always with the next election in mind. ${ }^{110}$ If this is an accurate description, it may fairly be said to comport with democracy, albeit somewhat murkily and imprecisely.

As an intuitive matter, it is difficult to dispute Alexander Bickel's comment that

no one has claimed that [pressure groups] have been able to capture the governmental process except by combining in some fashion, and thus capturing or constituting .... a majority. They often tend themselves to be majoritarian in composition and to be subject to broader majoritarian influences. And the price of what they sell or buy in the legislature is determined in the biennial or quadrennial electoral marketplace. ${ }^{111}$

Bickel goes on to rely on Dahl's thesis that if, because of pressure group coalitions, "the majority rarely rules on matters of specific policy, nevertheless the specific policies selected by a process of 
'minorities rule' probably lie most of the time within the bounds of consensus set by the important values of the politically active members of the society, of whom the voters are a key group."112 Bickel then offers the persuasive conclusion that if "we have 'minorities rule' rather than majority rule, it remains true nevertheless that only those minorities rule which can command the votes of a majority of individuals in the legislature who can command the votes of a majority of individuals in the electorate. In one fashion or another, both in the legislative process and at elections, the minorities must coalesce into a majority." 113

\section{The Role of the Executive Branch}

No appraisal of the democratic quality of the federal legislative system would be adequate without focusing on the executive branch as well.

The veto power, whose inherently negative nature has already been mentioned, ${ }^{114}$ and the fact that the administration is the principal source of legislation acted upon by Congress alone suggest the range of the consequential role played by the executive in the lawmaking process. But the President's influence is considerably greater in both striking and subtle ways. He may reach into a well-stocked arsenal of weapons to impose pressure on an individual congressman-by employing such carrots as granting patronage, awarding contracts in his district, supporting legislation he favors; and such sticks as withholding favors or, the ultimate penalty, opposing him for renomination or reelection. Even without reliance on the disputed ability to impound appropriated funds, ${ }^{15}$ it is fair to say that, in midtwentieth century America, few important federal policies may be enacted or effectuated without executive acquiescence.

Given the immense legislative power of the executive branch, the degree of its political responsibility bears critically on the principal questions addressed here. For example, it has been contended that the appointed federal civil service is more democratically representative than the elected Congress because it better mirrors the voters in origin, income level, attitudes, needs and desires, and associations. ${ }^{16}$ But in fact, it is the President himself, the single federal official with a nationwide

112 Id. 19 (citing Preface to Democracy, supra note 1, at 132).

${ }^{113} I d$.

${ }^{114}$ Text preceding note 58 supra.

115 See, e.g., Pennsylvania v. Lynn, 362 F. Supp. 1363 (D.D.C. 1973).

${ }^{116}$ N. Long, The Polity 70-71 (1962). 
constituency-politically accountable by election, in seeking his own reelection or that of his successor, and in courting popular support for a Congress sympathetic to his views-who greatly enhances the democratic image of the political branches.

This is not to say that the presidential will is equivalent to the enactment of legislation. Nor, even more clearly, is it to contend that the preference of the presidency is synonymous with majority rule-for both the systems of nomination and election contain pitfalls. The metaphoric "smoke-filled-room" process for choosing presidential nominees has a particular malodorous antidemocratic cast-an aroma by no means completely purified by some of the more recent reforms in convention delegate selection. Nonetheless, the increasing use of the presidential primary (although no majoritarian panacea) and the fact that the traditional convention process, despite the metaphor, has been substantially similar to "minorities rule" through pressure, negotiation and conciliation, both go much the distance in meeting the objections to the executive's majoritarian legitimacy.

The electoral college poses a major theoretical hurdle in the path of the presidential quest for majoritarian political legitimacy. Originally conceived to insulate the chief executive from the immediate heat of politics, early electors were usually chosen by state legislators rather than by the people. But this practice fell into disuse before the middle of the nineteenth century. Still, the electoral college method is less than pristinely democratic because of the possibility that the people's choice will be other than that of the electors and because of the tendency of unit voting to exaggerate the power of key groups of voters in swing states. ${ }^{117}$ Nonetheless, although more than a dozen presidential elections-including two of the last four-have produced plurality winners with less than a majority of the popular vote, only once in our history has the winner of the popular vote been denied election, and that was a century ago.

In sum, all these qualifications notwithstanding, it is fair to say that the American presidency does represent a majority of the people and comes closer to the majoritarian ideal than practically any other national office in the modern western democracies.

${ }^{117}$ Compare generally N. Polsay \& A. Wilddavsky, Presidential. Elections 166-72 (1964) (viewing the antidemocratic nature of the electoral college as a virtue) with $\mathrm{N}$. Peirce, The People's President (1968) (considering the same feature a vice). 
VI. The Political Accountability of the Supreme Court

As an interim conclusion it is clear that the national legislative process conducted by the political branches is not impeccable democracy in action. Infirmities appear at many important points on both its vertical and horizontal flow charts. But despite all the surface weaknesses, closer examination reveals an underlying and unshrinking core of popular responsibility-not pure majority rule, but rule by government broadly accountable to the majority. ${ }^{118}$ The burden of our inquiry, however, has not been simply to pass judgment on the democratic quality of the political branches. Rather, it has been the less onerous one of measuring this quality against that of the Supreme Court and judicial review. It must be acknowledged that the Court has often played a pivotal role in improving the democratic face of the political branches at all levels of government, particularly under the aegis of Earl Warren. In comparison to the Congress, however, the Court, at least as conventionally perceived, appears to be the less politically responsible branch.

The undemocratic appearance of the Court, however, requires more intense scrutiny before this conclusion may be held with real conviction. As has been noted, valiant efforts have been made to prove this image inaccurate. The most encompassing argument to "democratize" the Court's power as ultimate constitutional arbiter has been that judicial review, "from the beginning," has been tolerated by the people and their elected representatives; or, even more strongly, that because the citizenry wants certain of its leaders to preserve immutable and fundamental values against the hasty and ill-considered decisions that the voters and their other leaders will inevitably make, judicial review has been institutionally adopted by a continuing consensus of American society as an integral rule of the system; that, thus, judicial review operates by majority will, with the consent of the governed. ${ }^{119}$

Proper evaluation of this broadly sweeping contention necessitates review of the efficacy and legitimacy of both the general force of public reaction and the particular controls available to elected and appointed officials in responding to the Court's constitutional pronouncements. Almost two hundred

${ }^{118}$ Although state and local lawmaking bodies have been only sparingly mentioned, their majoritarian roots have been markedly enlarged through the elimination of malapportionment.

${ }^{119}$ See, e.g., C. Black, The People and the Court 209-12 (1960); J. Buchanan \& G. Tullock, supra note 23, at 260-62. 
years of judicial review show many periods of serious popular and political disagreement with the Court's work. Effective implementation of its decisions has greatly varied in degree from time to time and from case to case-and, not infrequently, the dynamics of the matter have been such that those rulings that have been least fulfilled were not those most strenuously opposed. Both literal and informal alterations of its decisions have occurred, but often only after considerable time has passed and their impact has already been meaningfully felt. And the most honored methods for political reversal of its judgments require extraordinary time and effort-more than simple majority will.

\section{A. Constitutional Amendment}

The amendment process, that technique of constitutional change with the most solid and dignified credentials, has been employed but four times in our history to overcome the Court's decisions, ${ }^{120}$ such meager utilization evidences the difficulty involved. More importantly, there is no more plainly designated antimajoritarian obstacle in our governmental system-nor, now that malapportionment is gone, no more clearly operative one -than the constitutionally prescribed amendment procedures.

\section{B. Political Control over Budget and Terms}

Less direct-and less reputable-political weapons for doing battle with the Court are available. Of minor significance, because used more in pique than with seriousness of purpose, is Congress' control over the Court's budget and over increases (but not reductions) ${ }^{\mathbf{1 2 1}}$ in the Justices' compensation. In addition, through its capacity to regulate the times when the Court sits, Congress may abolish certain of the Court's terms. Employed but once in our history, ${ }^{122}$ this technique is only of slightly more meaningful thrust because it is capable only of postponing, but not finally avoiding the Justices' pronouncements-although delay at a critical point or even for a brief period of time may sometimes accomplish much of what is desired.

120 U.S. ConST. amend. XI, adopted 1795-overruling Chisholm v. Georgia, 2 U.S. (2 Dall.) 419 (1793); U.S. CoNST. amend. XIV, § 1, adopted 1868-overruling Scott v. Sandford, 60 U.S. (19 How.) 393 (1857); U.S. ConST. amend. XVI, adopted 1913-overruling Pollack v. Farmers' Loan \& Trust Co., 157 U.S. 429 (1895); U.S. ConST. amend. XXVI, adopted 1971-overruling Oregon v. Mitchell, 400 U.S. 112 (1970).

121 U.S. Const. art. III, § 1.

${ }^{122}$ Act of Apr. 29, 1802, ch. 31, 1,2 Stat. 156, repealing in part Act of Sept. 24, 1789, ch. 20, § 1, 1 Stat. 73; Act of Mar. 8, 1802, ch. 8, § 1, 2 Stat. 132, repealing Act of Feb. 13, 1801, ch. 4, § 1, 2 Stat. 89. See 1 C. Warren, The Supreme Court In United States History 222-23 (1922). 


\section{Political Control over Composition}

Of greater import is the ability of the political branches to determine the Court's composition. The authority to impeach sitting Justices, the gravest aspect of this power, may be readily discredited as a factor that enhances the Court's democratic image. The legitimacy of its use due simply to disapproval of a Justice's votes or opinions cannot be seriously defended-though impeachment has been sought to be employed for this reason. Because of its severe consequences, prodigious energy is needed to put the impeachment machinery in motion. And the critical fact for our purposes is that the two-thirds Senate vote required for conviction strips it of any majoritarian pretenses.

The authority to appoint new Justices, vested in the President and-as several recent occurrences confirm, despite semantic quibbles-the Senate, may be seen as a powerful political tool to manipulate constitutional decisionmaking. But this ability alone, although its use to elevate persons of particular constitutional leanings is (or should be) unquestioned, depends upon natural fortuities beyond the reach of even the most indomitable President. It may will take several successive presidential terms-and, it merits reemphasis, cooperative Senates-to change the judicial philosophy of a majority of the bench. Moreover, it requires a keen executive prediction of appointees' present and future views on known and unknown issues, a clairvoyance that our history, even the most recent, has proven to fall far short of being wholly reliable. Even nominees who have been public figures in their own right with announced policy positions have disappointed presidential expectations once elevated to the Supreme Court. Manipulation through use of the appointment power further requires the assumption that the new appointees will disregard precedent. Although the willingness and ability to do this, even while denying that it is being done, is surely well supported by its own precedent, it nonetheless demands a readiness to depart from the strong tradition of stare decisis-a quantity that no President can buy with real assurance. In sum, the sustained efforts needed to reverse (or even halt) a course of constitutional interpretation through the appointing process is much greater than that required for virtually any legislative program-certainly for any that has the backing of a majority of the electorate.

The power of the political branches over the Court's composition includes the right to alter the number of Justices-to 
reduce the size of the Court and not fill vacancies, or to enlarge it by creating new seats. As a practical matter, the former course requires only executive action, or, more precisely, inaction. But even then the difficulties of awaiting normal attrition and depending on disregard of precedent remain, although perhaps in slightly ameliorated form. Probably because of these uncertainties, because executive nonuse of the appointment power for this end would be highly questionable in light of our constitutional traditions, and because this would constitute a de facto reduction of the Court's membership by the President alone without the consent of Congress, this method appears never to have been attempted. But history does provide several illustrations of efforts by Congress to diminish the number of positions-though more for the specific purpose of curtailing the influence of a President it opposed (Jefferson in 1801 and Johnson in 1866) than to reverse particular constitutional paths the Court had taken.

Achievement of this latter-and, for present purposes, more significant-goal has more often' been sought by the political departments through use of the power of increasing the number of Justices, coupled with the making of new appointments. After Chief Justice Marshall's departure in the Jackson administration, Justices were added, supposedly to counter his remaining influence. During the Civil War the Court's membership was briefly enlarged to ten, seemingly to afford a greater margin of security in response to the Court's closely split decision upholding the blockade of the Confederacy. The most dramatic example concerned the Legal Tender Cases. ${ }^{123}$ President Grant, on the day that Hepburn v. Griswold ${ }^{124}$ was decided, nominated two new Justices following a resignation and an increase in the Court's membership from eight to nine; in just a little more than a year, the Hepburn decision was overruled ${ }^{125}$ because of the votes of the new appointees. ${ }^{126}$

This last occasion, over a century ago, appears, however, to be the only clear victory achieved by the political branches in exercising the authority to enlarge. Indeed, the technique is distinguished not by success but rather by failure. Its most celebrated day occurred when President Franklin Roosevelt, just elected by an overwhelming popular majority and possessed of

12379 U.S. (12 Wall.) 457 (1871).

12475 U.S. (8 Wall.) 603 (1870) (5-3 decision).

${ }^{125}$ Legal Tender Cases, 79 U.S. (12 Wall.) 457 (1871) (5-4 decision).

${ }^{126}$ See E. Corwin, The President: Office and Powers 289 (4th ed. 1957). 
legendary influence over Congress, nonetheless saw his Courtpacking plan defeated, despite the extremely disreputable position of the Court for having thwarted both executive and legislative efforts to combat a great national crisis. Because of the Court's subsequent modification of its course, it may well be that the President, while losing the formal battle, won the larger campaign-though at very high cost, due to the widely acknowledged fact that his legislative mastery suffered greatly as a result. ${ }^{127}$ Yet the firmer facts are that, even under this extraordinary combination of auspicious circumstances, the Court's traditional independence of the political will survived, and that during subsequent periods of momentous judicial impact and unpopularity the political departments' power over the Court's composition, far from being seriously considered a consequential weapon, has been effectively discredited.

\section{Political Curtailment of Appellate Jurisdiction}

In the past quarter century, the device most frequently threatened by the political branches for use against the Court has been Congress' power, specified in article three, to make "Exceptions" to and "Regulations" of the Court's appellate jurisdiction. ${ }^{128}$ The starkness of the authorizing constitutional language appears to leave little room for disputing that Congress may divest the Court of its commission to review certain types or classes of cases, thus enabling the legislature to silence at least some of the Court's future constitutional pronouncements. The opinion of the Court itself, in the only executed congressional attempt in history to keep cases from it, gives credence to the existence of this broad legislative power. ${ }^{129}$ Thus viewed, this politically responsible authority goes far in sustaining the contention that the Court acts only with the acquiescence, albeit often passive, of the popular will and that there remains a forceful and formal democratic check on judicial review.

For a variety of reasons, however, the apparent cogency of the proposition suffers serious weakness. First, the theoretical underpinnings for a wide legislative power to curtail the appellate jurisdiction, only most scantily explored by the Court and usually in casual dicta, ${ }^{130}$ are hardly as firm as the literal phras-

${ }^{127}$ See J. Burns, Roosevelt: The Lton and the Fox 315 (1956).
${ }^{128}$ U.S. Const. art. III, $\$ 1$.
${ }^{129}$ See Ex parte McCardle, 74 U.S. (7 Wall.) 506 (1869).
${ }^{130}$ See Yakus v. United States, 321 U.S. $414,472-73$ (1944) (Rutledge, J., dissenting);
"Francis Wright," 105 U.S. 381 (1881); Ex parte McCardle, 74 U.S. (7 Wall.) 506 The "Francis Wright," 105 U.S. 381 (1881); Ex parte McCardle, 74 U.S. (7 Wall.) 506
(1869); Daniels v. Railroad Co., 70 U.S. (3 Wall.) 250, 254 (1865); Barry v. Mercein, 46 
ing of article three and the quite sweeping judicial language would suggest. A variety of interpretations of the delegated authority have been offered by prominent constitutional scholars, none of which results in any consequential political check on judicial review. Proceeding from such bases as the language itself and the intent and history of the Constitution as a whole, it has been plausibly argued that any casse "excepted" from the Supreme Court's appellate function must concomitantly be included within its original jurisdiction; ${ }^{131}$ that the pertinent clause of article three was meant only to permit restriction of the Court's review of questions of fact, not of substantive constitutional matters; ${ }^{132}$ that no matter how literally broad the general scope of legislative authority under article three, its exercise (like that of all delegated powers) is limited by other constitutional provisions, such as those in article one, section nine or in the Bill of Rights, which may themselves condemn certain denials of Supreme Court review to particular classes of persons; ${ }^{133}$ that, whatever the range of the power, it does not extend to the destruction of the essence of the Court's appellate function which contemplated ultimate resolution by the Justices of important federal questions; ${ }^{134}$ and that, if a case is "excepted" from the Court's appellate purview, then jurisdiction over it must be vested in a lower federal court and some path must remain to permit its constitutional questions to reach the Supreme Court on appeal. ${ }^{135}$ There is no need here to evaluate these theories. One need only conclude that the scope of congressional power to express discontent with the Court's work by legislation divesting it of certain jurisdiction is largely unresolved and totally unclear.

But even if this legislative ability to retaliate against the judiciary rested on a firm theoretical foundation, its pragmatic potential as a majoritarian restraint on judicial review would be severely limited. As Herbert Wechsler has lucidly revealed, since the political branches realize that the use of federal courts is essential to administer federal law-both for purposes of impos-

U.S. (5 How.) 103, $119-21$ (1847); Durousseau v. United States, 10 U.S. (6 Cranch.) 307 (1810); United States v. More, 7 U.S. (3 Cranch.) 159 (1805); Wiscart v. Dauchy, 3 U.S. (3 Dall.) 321,327 (1796) (Ellsworth, C.J.).

131 Van Alstyne, A Critical Guide to Marbury v. Madison, 1969 Duke L.J. 1, 32-33.

132 R. Berger, Congress v. The Supreme Court 285-96 (1969); Merry, Scope of the Supreme Court's Appellate Jurisdiction: Historical Basis, 47 Mins. L. Rev. 53 (1962).

${ }^{133}$ Van Alstyne, $A$ Critical Guide to Ex parte McCardle, 15 Ariz. L. Rev. 229 (1973).

134 Ratner, Congressional Power over the Appellate Jurisdiction of Federal Courts, 109 U.

PA. L. REv. 157 (1960). Cf. Hart, The Power of Congress to Limit the Jurisdiction of Federal Courts: An Exercise in Dialectic, 66 HaRv. L. Rev. 1362 (1953).

1351 W. Crosskey, Politics and the Constitution in the History of the United States 610-18 (1953). 
ing government coercion and enforcing private remediesCongress cannot, as a practical matter, withdraw all federal jurisdiction, even if it were authorized to do so constitutionally. If Congress instead were to choose only to curtail the Supreme Court's appellate jurisdiction, it could attempt to rest final resolution of all constitutional questions with the eleven federal courts of appeals. Although this may be preferable to leaving it to the highest courts of the fifty states-the result of abolishing all federal jurisdiction or of restricting the adjudication of some or all constitutional questions to the state courts-the potential for national inconsistency in constitutional interpretation would still be unbearable. Alternatively, the tradition of stare decisis could lead these other courts to follow the very Supreme Court decisions that sparked the congressional counteraction. "The jurisdictional withdrawal thus might work to freeze the very doctrines that had prompted its enactment, placing an intolerable moral burden on the lower courts. . . The federal system needs federal courts and the judicial institution needs an organ of supreme authority."136

This convincing line of argument helps explain why on only one occasion in American history-and that one of questionable significance in effect, and ultimately determined to be incomplete in scope ${ }^{137}$-has hostility prompted the political branches (Congress overriding a presidential veto) to utilize article three to diminish the Court's jurisdiction, though many such efforts have been made. Without discounting the possibility that certain resolute legislative threats, such as the Jenner bill ${ }^{138}$ in the 1950's, may have had some immeasurable impact on the Court's judgments, ${ }^{139}$ strong reliance cannot be placed on the political authority of article three if judicial review is to be democratized.

\section{E. Summary}

Based upon this survey of the various constitutional sources of indirect congressional and presidential authority that may serve as political brakes on the power of judicial review, it may be fairly concluded that their highly infrequent and largely ineffective use gravely undermines the view that the people have continuously approved of the Court's function simply because, in

${ }^{136}$ Wechsler, The Courts and the Constitution, 65 Colum. L. Rev. 1001, 1006-07 (1965).

${ }^{137}$ See Ex parte Yerger, 75 U.S. (8 Wall.) 85 (1869) (demonstrating that the act of Congress upheld in Ex parte McCardle, 74 U.S. (7 Wall.) 506 (1869), closed only one of the existing avenues of appeal to the Supreme Court).

${ }^{138}$ S. 2646, 85th Cong., 2d Sess. (1958).

${ }^{139}$ See W. Murphy, Congress and the Court 245-46 (1962). 
the main, they have allowed the Court to operate without constraints. In general, the constitutional legitimacy of the use of these devices against the Court's rule is greatly suspect; most may be seen as anticonstitutional in tradition, if not unconstitutional in law. Their exercise calls for one or the other of the elected branches to act affirmatively, and usually the concurrence of both is required; moreover, all the dominant forces of inertia - of maintenance of the status quo, of inaction due to the frequent absence of cohesive majorities and to the fragmentation of power-that are present in the national political process work to safeguard the Court, and indeed are magnified in the case of an attack on the Justices' historic independence. Thus, the majoritarian threat posed is more theoretical than real. Even if the necessary forces could be consolidated, any habitual use of the "unwieldy and overly blunt weapons ... . would have disastrous results on the judicial process; yet infrequent use of them is not enough to satisfy our democratic standards."140

\section{Conclusion}

The Supreme Court is involved in the political process in the sense that it participates in making public policy; it is not an organ of the political process in the sense that it is electorally responsible. The plan of the Constitution is that federal judges are appointed with life tenure for the precise purpose of shielding them from the popular will. The Justices stand in sharp contrast to the many highly placed and greatly influential executive and administrative officials who are also appointed, for the persons in this latter group are politically responsible: all of their terms of office are shorter; most are subject to removal at any time by the political branches, if not in law then in fact; Congress designates their authority with its desired specificity and may reverse their policies by ordinary legislation.

The most entrenched popular barriers to the rule of the Court are both more discrete and less formalized than those already mentioned. Although detailed exploration of the subject lies beyond the confines of this Article, some brief indication of the dynamics involved is appropriate here. If either of the political branches opposes a judicial doctrine that requires support for its effectuation-and many do, in varying degrees-the legislative or executive opportunity is clear. The presidential response may range from Abraham Lincoln's outright refusal to

${ }^{140}$ McCleskey, supra note 2, at 364 . 
obey Chief Justice Taney's order in Ex parte Merryman, ${ }^{141}$ to Andrew Jackson's alleged edict that he would leave John Marshall to enforce his own decision in the Cherokee Indian Cases, ${ }^{142}$ to Dwight Eisenhower's seeming ambivalence immediately following Brown v. Board of Education. ${ }^{143}$ The congressional power of the purse may also be employed to enfeeble the Court's will, as is illustrated by the recent repeated efforts to deny funds for school busing to achieve racial desegregation. ${ }^{144}$ (At the opposite pole, the spending power may be used as a sharp-edged sword to obtain conformity to judicial rulings-as is exemplified by the enormous progress in southern school desegregation that immediately (and only) followed Congress' threat to withhold federal funds from noncomplying districts.) Furthermore, lesser officials (including the judges) at all levels of government, and, ultimately, the people themselves, may move grudgingly and hesitatingly in adhering to the Court's mandate, ${ }^{145}$ or they may simple refuse to obey, with varying degrees of blatancy. ${ }^{146}$

Whether these types of conduct abide by the social compact of American society and whether they are constitutionally justifiable is beyond the scope of this Article. Perhaps due to their availability there is truth in the observations that "the Supreme Court has seldom, if ever, flatly and for very long resisted a really unmistakable wave of public sentiment,"147 and that "when either [Congress or the President] has chosen to fight

${ }^{142} 17$ F. Cas. 144 (C.C.D. Md. 1861).

142 President Jackson's exact words in response to the decision in Cherokee Nation v. Georgia, 30 U.S. (5 Pet.) 1 (1831), were said to be: "John Marshall has made his decision. Now let him enforce it." W. Sumner, Andrew Jackson as a Public Man 182 (1893) (citing I H. GReeley, The AMerican Conflict 106 (1873)).

${ }_{143} 347$ U.S. 483 (1954), remanded for formulation of decrees, 349 U.S. 294 (1955).

144 See, e.g., Act of June 23, 1972, Pub. L. No. 92-318, tit. VIII, 86 Stat. 235, 371.

145 For example, see the numerous empirical studies describing degrees of noncompliance with the Court's invalidations of religious practices in the public schools. Dolbeare \& Hammond, Inertia in Midway: Supreme Court Decisions and Local Responses, 23 J. LEG. ED. 106 (1970); Katz, Patterns of Compliance with the Schempp Decision, 14 J. PUB. L. 396 (1965); Patric, The Impact of a Court Decision: Aftermath of the McCollum Case, 6 J. PuB. L. 455 (1957); Reich, Schoolhouse Religion and the Supreme Court: A Report on Attitudes of Teachers and Principals and on School Practices in Wisconsin and Ohio, 23 J. Leg. ED. 123 (1970); Sorauf, Zorach v. Clauson: The Impact of a Supreme Court Decision, 53 AM. PoL. ScI. REv. 777 (1959).

Other studies discuss response to the Court's proscriptions of various law enforcement practices. F. Graham, The Self-INflicted Wound (1970); Medalie, Zeitz \& Alexander, Custodial Police Interrogation in Our Nation's Capital: The Attempt to Implement Miranda, 66 Mich. L. Rev. 1347 (1968); Note, Interrogations in New Haven: The Impact of Miranda, 76 YALE L.J. 1519 (1967).

${ }^{146}$ See, e.g., Beatty, State Court Evasion of United States Supreme Court Mandates During the Last Decade of the Warren Court, 6 VAlP. U.L. REv. 260 (1972); Warren, Legislative and Judicial Attacks on the Supreme Court of the United States-A History of the Twenty-Fifth Section of the Judiciary Act, 47 AM. L. REv. 1, 161 (1913); 67 HARv. L. REv. 1251 (1954); 56 YALE L.J. 574 (1947).

${ }^{147}$ R. McCloskey, The American Supreme Court 23 (1960). 
back the Court has generally failed, in the long min, to stop the two branches permanently." 148 But, for present purposes, the carefully injected qualifications contained within these statements are more significant than the generalizations. ${ }^{149}$ Similarly, perhaps there is validity in the conclusion that the visibly ascending threat of the more formal, but constitutionally even more debatable, political sanctions discussed above, when supported by a hostile national temper, will ultimately persuade the Court to bend from a course of decisions. ${ }^{150}$

Neither this reasoning nor its supporting data, however, lead to the conclusion that judicial review is compatible with majoritarian democracy as traditionally conceived or practiced. Many eventful and controversial constitutional decisions-especially those involving use of the judicial system itself (as in the field of criminal procedure)-although subject to being undercut by resentful administrative officials and lower courts, do not depend for their complete effectiveness on the cooperation of other public agencies or of the people in general. Further, it must be conceded that it is only those Supreme Court mandates perceived as exceedingly flagrant that are capable of generating the intensity of opposition necessary to prevent enforcement. Nor is popular resistance universal in impact, either geographically or temporally; even if certain rulings eventually fall into disuse because of opposition by the requisite majority will, their force will be felt by a segment of the people for some time and often by many of the people for a long time. And impelling the Court to bend or draw up in developing doctrine falls far short of causing the Court to break or retreat.

At the surface, the antimajoritarian features of all three federal departments bear a certain similarity. The leeway afforded the political branches by the people and the tenacity of popular feeling needed for radical change through election revolt are not absolutely different from the independence granted the judiciary by the Constitution and the assiduous efforts required to affect the Court and its decisions through the restraints ultimately retained by the citizenry and their elected representatives. But in both democratic theory and practice, the distinction between control of the legislature and executive on one side and control of the judiciary on the other, if not one of

${ }^{148}$ Abraham, Machtkampf: The Supreme Court of the United States in the Political Process, 13 PARL. Affairs 424, 428 (1960).

149 Note Henry Abraham's further view that "the Court does make many of its major constitutional decisions stick." Id. 430.

150 See C.H. Pritchett, Congress Versus the Supreme Court 133 (1961). 
kind, is one of substantial degree. That a majority of the people may ultimately prevail vis-á-vis the Court by outright resistance or through methods of dubious legitimacy under a rule of law, even if a reality, is not the same as their ordained ability to change the composition of the political branches at regularly scheduled periodic elections. Even if the Court can accomplish little beyond delaying strong popular passions-and the hard evidence for this is sparse and spotty at very best-so that its declarations of unconstitutionality do no more than afford the people a "sober second thought," 151 the Court's role far exceeds Burke's most aggrandized view of a political trusteeship, because of the extraordinary time and energy required for finally successful political inebriation.

The case may be an uneasy one, but given a realistic and balanced view of the operation of the political branches, and especially considering the predominantly negative quality of their antimajoritarianism, the Supreme Court is not as democratic as the Congress and President and the institution of judicial review is not as majoritarian as the lawmaking process. The sundry controls of the people and their elected representatives may succeed in some instances and pose perilous threats in others. But these political checks do not democratize the Court or its power of judicial review. To the contrary, as I have urged elsewhere, ${ }^{152}$ the essential role of judicial review in our society is to guard against certain constitutional transgressions specifically sought to be imposed by popular majorities. Furthermore, the effect of these antijudicial weapons (blunt as they are) is not to guarantee that only rulings with popular support are effectuated, nor even to assure that only those decisions that draw intense popular opposition are denied-although that would be democracy in action, no matter how antithetical to the core of our constitutional plan. Rather, when used or threatened, these political instruments operate overbroadly and haphazardly, often undermining large areas of the Court's fundamental obligation in indiscriminate fashion, thus plurally frustrating the Court's vital functions. The great task for the Court, then, is how best to reject majority will when it must, without endangering not only that critical role but its other urgent duties as well.

151 The phrase is Chief Justice Stone's in The Common Law in the United States, 50 Harv. L. Rev. 4, 25 (1936).

152 Choper, On the Warren Court and Judicial Review, 17 Cath. U.L. Rev. 20 (1967). 